\title{
Two decades of water vapor measurements with the FISH fluorescence hygrometer: a review
}

\author{
J. Meyer ${ }^{1, a}$, C. Rolf ${ }^{1}$, C. Schiller ${ }^{1, \dagger}$, S. Rohs ${ }^{1,2}$, N. Spelten ${ }^{1}$, A. Afchine ${ }^{1}$, M. Zöger ${ }^{3}$, N. Sitnikov ${ }^{4}$, T. D. Thornberry ${ }^{5,6}$, \\ A. W. Rollins ${ }^{5,6}$, Z. Bozóki ${ }^{7,8}$, D. Tátrai ${ }^{7,8}$, V. Ebert $^{9,10}$, B. Kühnreich ${ }^{9,10}$, P. Mackrodt ${ }^{9}$, O. Möhler ${ }^{11}$, H. Saathoff ${ }^{11}$, \\ K. H. Rosenlof ${ }^{5}$, and M. Krämer ${ }^{1}$ \\ ${ }^{1}$ Institut für Energie und Klimaforschung 7, Forschungszentrum Jülich, 52425 Jülich, Germany \\ ${ }^{2}$ Institut für Energie und Klimaforschung 8, Forschungszentrum Jülich, 52425 Jülich, Germany \\ ${ }^{3}$ Deutsches Zentrum für Luft und Raumfahrt, FX, 82234 Oberpfaffenhofen, Germany \\ ${ }^{4}$ Central Aerological Observatory, Dolgoprudny, Russia \\ ${ }^{5}$ NOAA ESRL Chemical Sciences Division, Boulder, CO, USA \\ ${ }^{6}$ Cooperative Institute for Research in Environmental Sciences, University of Colorado Boulder, Boulder, CO, USA \\ ${ }^{7}$ Department of Optics and Quantum Electronics, University of Szeged, Szeged, Hungary \\ ${ }^{8}$ MTA-SZTE Research Group on Photoacoustic Spectroscopy, Szeged, Hungary \\ ${ }^{9}$ Physikalisch-Technische Bundesanstalt (PTB), 38116 Braunschweig, Germany \\ ${ }^{10}$ Reaktive Strömungen und Messtechnik, Technische Universität Darmstadt, 64287 Darmstadt, Germany \\ ${ }^{11}$ Institute for Meteorology and Climate Research (IMK-AAF), Karlsruhe Institute of Technology, \\ 76344 Eggenstein-Leopoldshafen, Germany \\ ${ }^{a}$ now at: Institute of Energy and Environmental Technology (IUTA), 47229 Duisburg, Germany \\ $\dagger$ deceased
}

Correspondence to: C. Rolf (c.rolf@fz-juelich.de)

Received: 17 December 2014 - Published in Atmos. Chem. Phys. Discuss.: 12 March 2015

Revised: 9 July 2015 - Accepted: 10 July 2015 - Published: 30 July 2015

\begin{abstract}
For almost two decades, the airborne Fast Insitu Stratospheric Hygrometer (FISH) has stood for accurate and precise measurements of total water mixing ratios (WMR, gas phase + evaporated ice) in the upper troposphere and lower stratosphere (UT/LS). Here, we present a comprehensive review of the measurement technique (Lyman$\alpha$ photofragment fluorescence), calibration procedure, accuracy and reliability of FISH. Crucial for FISH measurement quality is the regular calibration to a water vapor reference, namely the commercial frost-point hygrometer DP30. In the frame of this work this frost-point hygrometer is compared to German and British traceable metrological water standards and its accuracy is found to be $2-4 \%$. Overall, in the range from 4 to $1000 \mathrm{ppmv}$, the total accuracy of FISH was found to be $6-8 \%$, as stated in previous publications. For lower mixing ratios down to $1 \mathrm{ppmv}$, the uncertainty reaches a lower limit of 0.3 ppmv. For specific, non-atmospheric conditions, as set in experiments at the AIDA chamber - namely mixing ratios below 10 and above $100 \mathrm{ppmv}$ in combination with high- and low-pressure conditions - the need to ap-
\end{abstract}

ply a modified FISH calibration evaluation has been identified. The new evaluation improves the agreement of FISH with other hygrometers to $\pm 10 \%$ accuracy in the respective mixing ratio ranges. Furthermore, a quality check procedure for high total water measurements in cirrus clouds at high pressures $(400-500 \mathrm{hPa})$ is introduced. The performance of FISH in the field is assessed by reviewing intercomparisons of FISH water vapor data with other in situ and remote sensing hygrometers over the last two decades. We find that the agreement of FISH with the other hygrometers has improved over that time span from overall up to $\pm 30 \%$ or more to about $\pm 5-20 \% @<10$ ppmv and to $\pm 0-15 \%$ @ > 10 ppmv.

As presented here, the robust and continuous calibration and operation procedures of the FISH instrument over the last two decades establish the position of FISH as one of the core instruments for in situ observations of water vapor in the UT/LS. 


\section{Introduction}

Water vapor in the upper troposphere and lower stratosphere (UT/LS) plays an important role in the climate of the Earth. It is a basic component in ozone photochemical processes in the lower stratosphere (Vogel et al., 2011) and its concentration also affects the formation of clouds (Pruppacher et al., 1997). Water vapor's direct role as a greenhouse gas and its indirect role in cloud formation processes have significant impacts on the radiation budget of the Earth (Solomon et al., 2010; Forster et al., 2002; Smith et al., 2001; Wang et al., 1976). For example, isentropic transport of moist air from the upper tropical troposphere to the lower stratosphere (LS) affects the radiative budget in two ways. Directly it produces an increase in water vapor in the dry LS and indirectly it impacts thin cirrus formation near the tropopause (Dessler et al., 2009; Spang et al., 2014).

Accurate measurements of water in the UT/LS are required to understand the underlying exchange, dehydration, and transport processes (Ploeger et al., 2006) and to provide input data for atmospheric and climate models (e.g., Solomon et al., 2010; Riese et al., 2012). One prominent example is the discussion Peter et al. (2006) inspired about observed massive supersaturations in the atmosphere, which seemed to contradict the understanding of the microphysics of ice formation. As a result, new, so far unknown microphysical processes were sought and intensive reviews of measurement uncertainties were initiated. As a side note, this "supersaturation puzzle" was further investigated based on FISH measurements as reported by Krämer et al. (2009). They applied a quality check procedure to in-cloud supersaturation measurements and could explain all valid supersaturations by established microphysics.

Due to the difficulties measuring water vapor in the UT/LS region, global or long-term observations of stratospheric water vapor are rare (Rosenlof et al., 2001; Hurst et al., 2011). Consequently, Rosenlof et al. (2001) and Kley et al. (2000) combined water vapor measurements from different instruments to derive long-term changes of stratospheric water. They identified systematic differences between individual hygrometers on the order of $20 \%$, which was partially accounted for by the relative trend analysis of that study. However, for many other applications, such as radiation calculations and cloud formation studies, the absolute accuracy of the water measurement is essential.

Since the first comprehensive comparison of hygrometers specifically designed to measure in the UT/LS region (Kley et al., 2000, see Sect. 5.1), larger systematic discrepancies between hygrometers have been reported. At mixing ratios below $10 \mathrm{ppmv}$, and particularly below 5 ppmv, differences may be on the order of several tens of percent (Weinstock et al., 2009; Fahey et al., 2014) and thus exceed the combined uncertainties stated for the individual hygrometers. As a result of this dilemma, laboratory and aircraft-based intercomparisons were organized between 2007 and 2013 (see, e.g.,
Fahey et al., 2014; Rollins et al., 2014) and the measurement quality of the individual hygrometers was reassessed.

This study presents the results of an extensive review process for the Fast In-situ Stratospheric Hygrometer (FISH), which was developed at the Forschungszentrum Jülich. FISH has been used for atmospheric measurements of water vapor in the UT/LS region for more than two decades. The current version of the instrument is an update of the instrument described in Zöger et al. (1999). It was redesigned to run in an automatic mode. FISH has been integrated on a variety of different platforms, including balloons, a number of different aircraft (Geophysika, Learjet, Falcon, HALO, WB-57) and laboratory facilities (AIDA). Over the years, FISH has participated in a number of field campaigns in the tropics, mid latitudes and the polar region (a subset is given in Table 1 of Schiller et al., 2008). A map of all 348 FISH aircraft flights is shown in Fig. 1. From these flights, a unique set of UT/LS water vapor data is compiled. FISH measurements have been used in both high-precision process studies and climatological studies with respect to water vapor transport (e.g., Kunz et al., 2008, 2014) or cirrus ice water content (Schiller et al., 2008; Krämer et al., 2009; Luebke et al., 2013). Thus, after more than two decades of operation and more than 100 publications including FISH measurements, a comprehensive review of the measurement principle, calibration procedure and data evaluation of water vapor data from the FISH instrument was performed and is presented in the following sections of this paper. Additionally, the consistency of the FISH measurements with other in situ and remote sensing hygrometers is reported.

\section{FISH-technique - a brief description}

The Fast In-Situ Stratospheric Hygrometer (FISH), described in detail by Zöger et al. (1999), was developed for fast and precise airborne and balloon-borne measurements of low water vapor concentrations in the lower stratosphere. Over the years, FISH was also applied for airborne measurements in the upper troposphere with higher water vapor concentrations.

FISH is a "closed path hygrometer"; i.e., the instrument is mounted inside of the respective platform and the sample air must be supplied via a tube. On an aircraft, this tube is in most cases connected to a forward facing inlet supplying a free flow through the measuring cell driven by the pressure difference between the inlet and gas outlet. An advantage of this system is that the flow rate is high enough ( $\geq 10$ standard liter per minute in the UT/LS) to reduce the effect of significant contamination of the water signal by outgassing of water molecules from the walls of the inlet system and the closed cell (see Sect. 3.2). During cloud penetrations, ice particles that also enter the inlet, which is heated, sublimate and thus a signal of ice water content is added to the gas-phase water (see Sect. 4.4 or Schiller et al., 2008). 


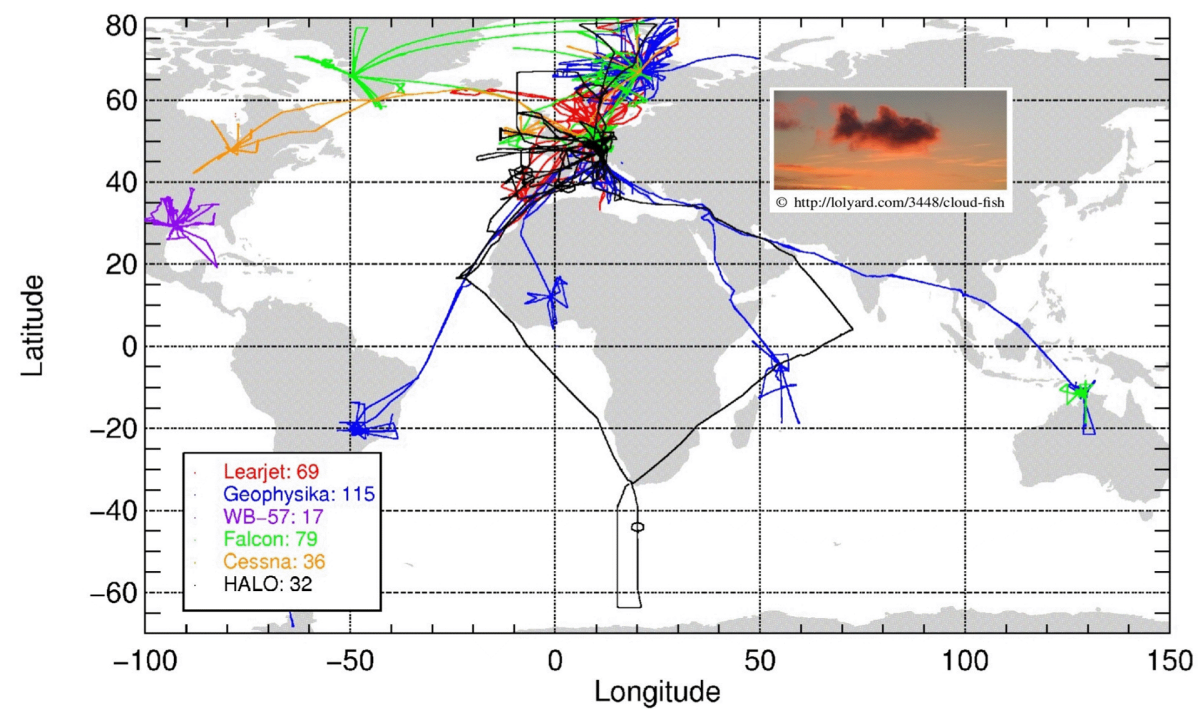

Figure 1. FISH (Fast In-situ Stratospheric Hygrometer) map of 348 aircraft flights. The "fish cloud" is in memory of our colleague Cornelius Schiller - see also dedication at the end of the paper.

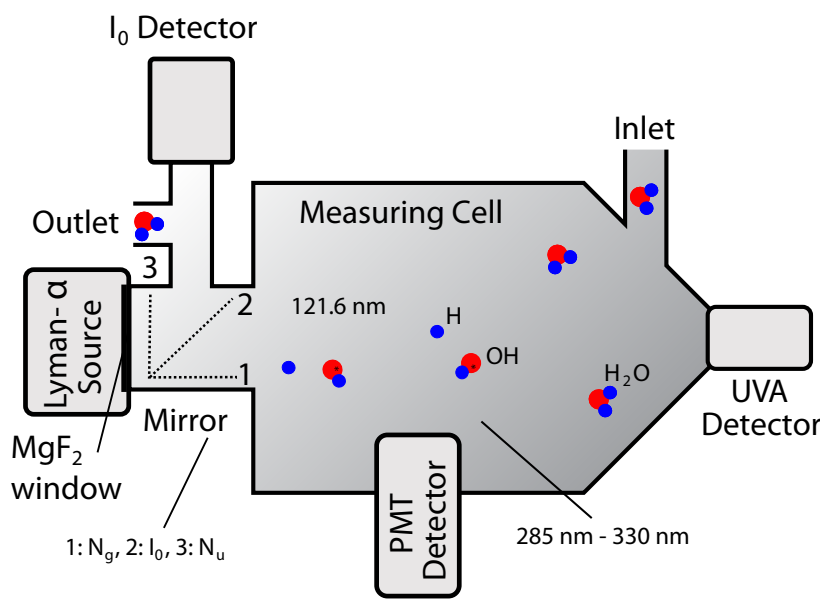

Figure 2. Conceptual diagram illustrating the principal mechanical and optical components of the FISH. The size of the cell is $0.3 \mathrm{~L}$ in total.

The measurement principle used by FISH is based on photofragment fluorescence (a sketch of the FISH design is displayed in Fig. 2): water molecules are split into an excited $\mathrm{OH}$ molecule and a single $\mathrm{H}$ atom by Lyman- $\alpha$ radiation $(121.6 \mathrm{~nm})$. The excited $\mathrm{OH}$ molecules emit radiation in the $285-330 \mathrm{~nm}$ range when relaxing to the ground state. This emitted radiation is detected by a photomultiplier tube (PMT). The number of detected fluorescence photons $N_{\mathrm{g}}$ is proportional to the water vapor mixing ratio (WVMR) with a calibration factor $c_{\mathrm{k}}$. This calibration factor is determined prior to each experiment in the laboratory (see Sect. 3).

FISH consists of a vacuum-tight measuring cell, the Lyman- $\alpha$ radiation lamp, the PMT in photon-counting mode

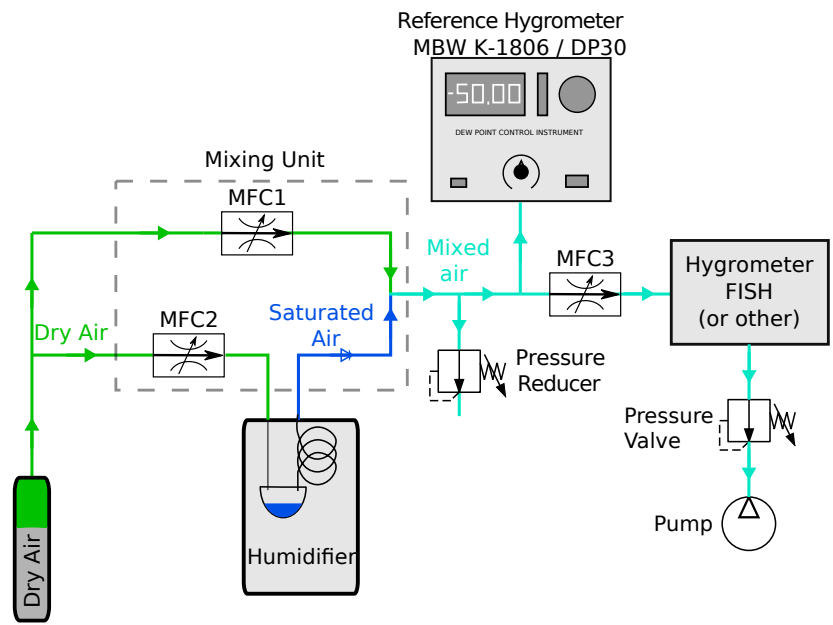

Figure 3. This diagram illustrates the principal setup of the Jülich calibration bench. The colored paths (green, dark and light blue) indicate the air flow through the system. Green and dark blue represent the flow of dry and water saturated air, respectively. The userdefined, stable humidity level generated by mixing the dry and saturated air is colored in light blue.

and detectors to monitor the Lyman- $\alpha$ intensity $I_{0}$ and the lamp intensity reduced by water vapor absorption (UVA) in the cell (see Fig. 2). The Lyman- $\alpha$ radiation lamp operates with a constant flow $\left(2 \pm 0.05\right.$ standard $\left.\mathrm{mL} \mathrm{min}^{-1}\right)$ of an argon and hydrogen mixture (ratio 99/1) and maintains a constant emission by RF-excited discharge (details in Zöger et al., 1999).

As the lamp is not monochromatic, the number of lamp background counts also has to be taken into account. Therefore a swiveling mirror is implemented between the lamp and 
the measuring cell. During one measurement cycle the mirror is placed in three different positions to determine the total fluorescence rate $N_{\mathrm{g}}$ (mirror position 1), the background rate $N_{\mathrm{u}}$ (mirror position 3 ) and the lamp intensity $I_{0}$ (mirror position 2).

$I_{0}$ has to be recorded because the Lyman- $\alpha$ intensity depends on the pressure in the cell due to a changing number of absorbing oxygen molecules and higher atmospheric $\mathrm{H}_{2} \mathrm{O}$ concentrations in the light path. This recording avoids any influence of lamp intensity changes, e.g., by aging of the $\mathrm{MgF}_{2}$ window that is placed between the Lyman- $\alpha$ source and the measuring cell, on the water vapor measurement. The water vapor mixing ratio can now directly be determined using the so-called FISH equation:

$\mu=c_{\mathrm{k}} \cdot \frac{N_{\mathrm{g}}-f_{\mathrm{u}} \cdot N_{\mathrm{u}}}{I_{0} \cdot K_{\mathrm{f}}}$,

where $f_{\mathrm{u}}$ is a second calibration constant accounting for transmission loss by the mirror during the background measurements (see Sect. 3). The pressure-dependent $K_{\mathrm{f}}$ factor considers non-radiative transitions of the excited $\mathrm{OH}$ into the ground state (for details see Zöger et al., 1999). Since FISH measures mixing ratios, this factor is close to 1 at high pressures $(\sim 1000 \mathrm{hPa})$ and less than 1 at lower pressures (e.g., 0.975 at $100 \mathrm{hPa}$ ).

The characteristics of FISH that guarantee a highly accurate measurement of the WVMR $\mu$ are (i) the regular recording of $I_{0}$ and $N_{\mathrm{u}}$ and (ii) frequent calibration with an automated calibration bench to determine $c_{\mathrm{k}}$ and $f_{\mathrm{u}}$, which is described in the next section.

\section{FISH calibration procedure - an update}

The core of the FISH data evaluation is the calibration of the fluorescence signal. Thus, FISH is regularly connected to a calibration bench to determine the calibration coefficients $c_{\mathrm{k}}$ and $f_{\mathrm{u}}$ needed to calculate the WVMR $(\mu)$ via Eq. (1) (see Sect. 2). The Jülich calibration bench consists of three parts (Fig. 3): a humidifier, a mixing unit to mix dry and humid air and a reference water vapor instrument. The current reference water vapor instrument is a commercially available MBW Dew Point instrument (model K-1806/DP30-SHSXIII, MBW Elektronik AG, Switzerland, www.mbw.ch), in the following denoted as DP30. The previous reference instrument, a General Eastern type 1311DRX frost-point hygrometer, was replaced in 2001. Another version of the MBW frostpoint hygrometer portfolio, the MBW $373 \mathrm{LX}$, is currently under evaluation for use as a reference. Inside the DP30, the thickness of a frost layer on a mirror is optically monitored and held constant by a heating and cooling system. The temperature of the mirror is measured and hence the water vapor content can be determined by means of the water vapor saturation pressure formula. The accuracy of the DP30 is $\pm 0.1{ }^{\circ} \mathrm{C}$ frost point and the instrument can measure equi- librium temperatures between -75 and $+20^{\circ} \mathrm{C}$ at a constant pressure of 2 bar. Today, two DP30 instruments are in use in the Jülich laboratories in order to detect potential drifts of individual instruments. The accuracy of the reference instruments will be discussed in Sect. 4.1.

Via the mixing unit, different humidity levels can be generated during a calibration cycle. Standard calibrations cover humidity levels between 1 and several 100 ppmv relevant for the UT/LS. In addition, the pressure within the FISH measuring cell can be adjusted independently to account for variable conditions.

\subsection{FISH calibration}

The standard calibration procedure is automated and covers the range of 2 to $\sim 450 \mathrm{ppmv}$ in six steps. At each humidity step, five different pressure levels between 30 and $350 \mathrm{hPa}$ are scanned. A calibration is performed during airborne campaigns after a maximum of two flights, ideally after each flight. Since in the field the supply of dry air is often limited, the calibrations are performed at low flow rates of about 5 standard liter per minute (standard $\mathrm{L} \mathrm{min}^{-1}$ ) to minimize the amount of dry air per calibration. Deviations of the FISH WVMR caused by the low flow rate can be accounted for (discussed later in Sect. 3.2), but do not occur during flight conditions where the typical flow rates at altitudes between 500 and $80 \mathrm{hPa}$ range from 30 to 10 standard $\mathrm{L} \mathrm{min}^{-1}$. With a cell volume of $0.3 \mathrm{~L}$, the exchange range for air in the cell is $0.3-0.15 \mathrm{~s}$.

Figure 4 displays a FISH calibration run, both in linear scaling to highlight the high WVMR range and in logarithmic scaling to visualize the lower WVMR. The blue line shows the DP30 signal illustrating the six chosen WVMR steps, while the black line represents the cell pressure variations. The red line denotes the FISH signal, using coefficients $c_{\mathrm{k}}=0.00209$ and $f_{\mathrm{u}}=3.47$ derived from this particular calibration run. The calibration factors are determined by rearranging Eq. (1) to

$$
\frac{1}{c_{\mathrm{k}}}+\frac{N_{\mathrm{u}}}{I_{0} \cdot \mu_{\mathrm{DP} 30}} \cdot f_{\mathrm{u}}=\frac{N_{\mathrm{g}}}{I_{0} \cdot \mu_{\mathrm{DP} 30}},
$$

and then applying a linear fit where the $y$ intercept (first term) is the inverse of $c_{\mathrm{k}}$ and $f_{\mathrm{u}}$ is the slope of the line.

The WVMRs of FISH and DP30 show a very good agreement for most of the calibration conditions, except for the lowest and highest mixing ratios steps. Here, a dependence of the WVMR on the cell pressure can be seen (see Fig. 4), which is not considered in the linear FISH calibration (Eq. 1), and thus points to some deviations from the idealized measurement principle described above.

In the low humidity range, the measured water content decreases for the highest pressure levels, while for the high humidity range the pressure behavior is reversed; i.e., the measured water vapor amount increases with increasing pressure in the FISH measuring cell. This effect also becomes 

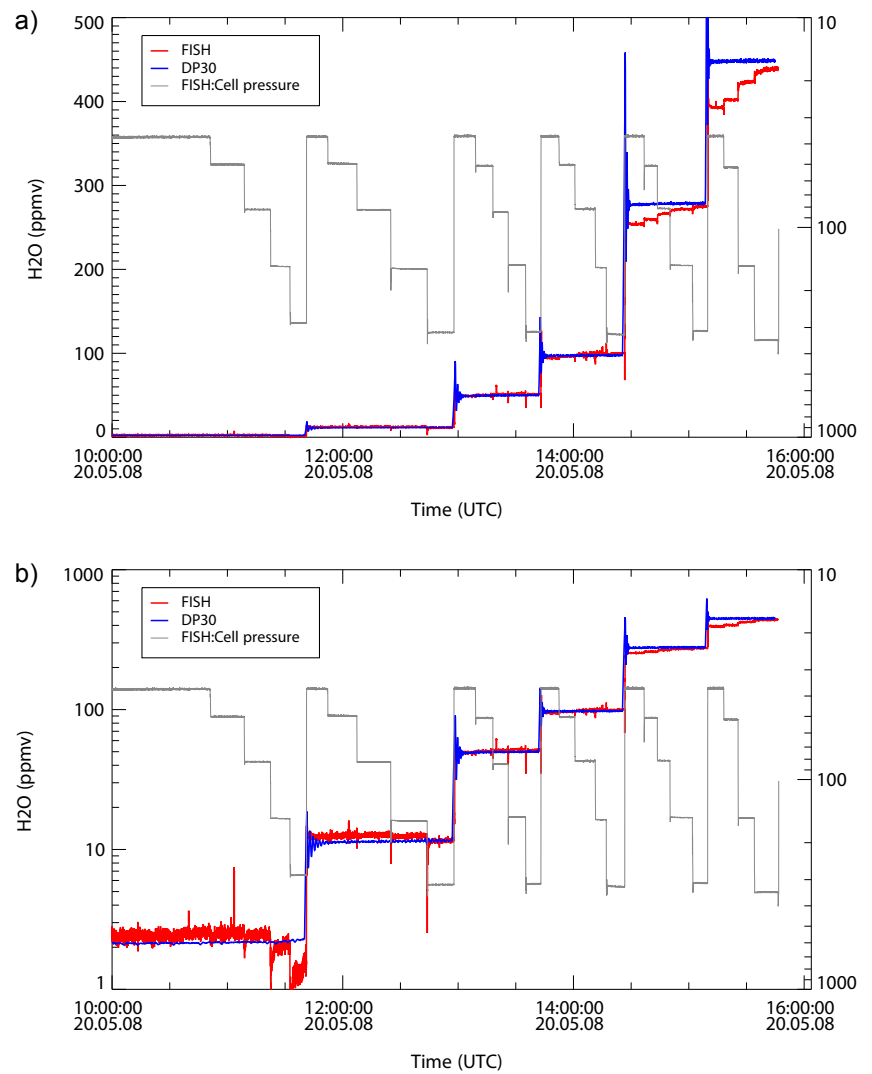

Figure 4. FISH and DP30 WVMR time series measured with the Jülich calibration bench with a flow rate of 5 standard $\mathrm{L} \mathrm{min}^{-1}$. (a) linear scale; (b) logarithmic scale.

obvious during experiments at the AIDA chamber, where experiments under atmospherically atypical conditions (low WVMR/high pressure, high WVMR/low pressure) were performed, e.g., during the AquaVIT-1 and AquaVIT-2 campaigns in 2007 and 2013 (see Sect. 5.2).

\subsection{Extended FISH calibration evaluation}

For low humidities and low flow rates, the relative contribution of additional water sources in the FISH system may become important. Although leakages are carefully avoided in the FISH measuring system, outgassing of small amounts of water from surfaces inside the FISH flow system cannot be completely suppressed under such conditions. This effect becomes increasingly important the lower the flow rate through the cell and the smaller the amount of water vapor in the sample flow. As outgassing is mainly controlled by the water vapor partial pressure difference between the gas flow and the adsorbed water on the wall surface, the water content added from the walls decreases with increasing cell pressure $P$ (see Fig. 4b) up to the equilibrium pressure $P_{\text {eq. }}$ where the partial pressure difference vanishes.

One way to minimize the effect of outgassing on low water vapor contents is to keep the air flow through the FISH mea-
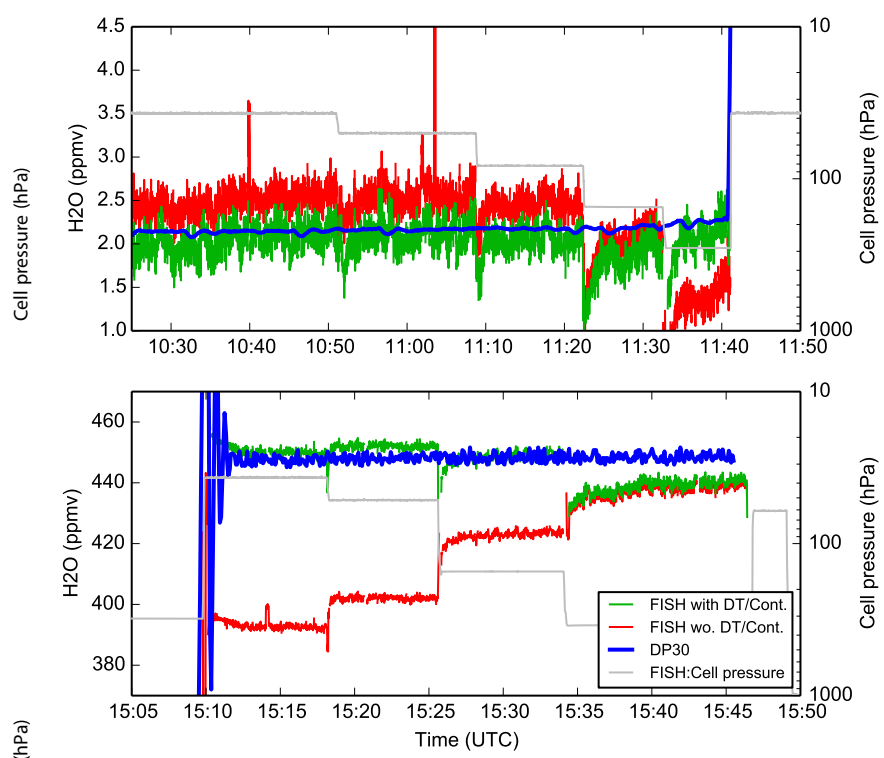

Figure 5. Lowest and highest level of the same calibration shown in Fig. 4, but calculated with the modified calibration equations (green line). For more detail see text.

suring cell above 10 standard $\mathrm{Lmin}^{-1}$, which is always the case for airborne FISH measurements in the inlet forward mode (see Sect. 2). For lower flow rates, as used for laboratory experiments, the effect can be addressed by including an additional calibration factor $X_{\mathrm{w}}$ and a pressure- and flowdependent term to Eq. (1) as follows:

$\mu=c_{\mathrm{k}} \cdot \frac{N_{\mathrm{g}}-f_{\mathrm{u}} \cdot N_{\mathrm{u}}}{I_{0}}-c_{\mathrm{k}} \cdot X_{\mathrm{w}} \cdot \frac{\left(P_{\text {eq. }}-P\right) \cdot I_{0}}{\text { flow }}$.

Applying this modification to the FISH equation results in a constant $f_{\mathrm{u}}$ factor of 1.1 to 1.2 for different calibration runs, which is close to the theoretical value of 1.15 . When using Eq. (2) to calculate $f_{\mathrm{u}}$, it ranges between 1.2 and 4, since the slope is very sensitive to variations in low humidity steps (high $N_{\mathrm{u}} /\left(I_{0} \cdot \mu_{\mathrm{DP} 30}\right)$ values).

Figure 5 (top panel) shows the effect of Eq. (1) (red curve) vs. Eq. (3) (green curve) on the calculated WVMR for the same calibration as shown in Fig. 4. It can be clearly seen that using Eq. (3) results in a better agreement between FISH and DP30 (blue curve).

For high humidities, the response time of the detector system limits the functionality of FISH. In general, the intensity of the generated fluorescence radiation increases with increasing water vapor content. Thus, the time between subsequent counts detected by the photomultiplier PMT becomes shorter with a higher amount of water vapor molecules in the air. As the PMT sensor and the electronics needs a certain time to process the signal produced by one fluorescence photon, additional photons will not be processed and thus not counted in this so-called dead time. The dead time of the PMT sensor system and the processing electronics was experimentally determined to be DT $=370 \mathrm{~ns}$. 
The PMT count rate, $N_{\mathrm{g}}$, at one humidity level is higher at lower pressures due to less absorption of the Lyman- $\alpha$ by oxygen. In fact, the fluorescence count rate $N_{\mathrm{g}}$ is much more sensitive on the Lyman- $\alpha$ intensity than on the number of water vapor molecules in the cell. The loss of counts due to the detector dead time is thus much more pronounced at lower pressures in the FISH measuring cell under high humidity conditions (atypical for the atmosphere). As the water vapor content measured during operation on aircraft in the UT/LS is usually low, this effect on the airborne FISH measurements is negligible. For laboratory experiments, however, the impact of the detector dead time on the measured count rate $N_{\mathrm{g} \text {,meas }}$ can be corrected by assuming a Poisson process for incoming photons:

$N_{\mathrm{g}, \text { true }}=\frac{N_{\mathrm{g}, \text { meas }}}{1-N_{\mathrm{g}, \text { meas }} \cdot \mathrm{DT}}$.

Figure 5 (bottom panel) displays the highest WVMR level from the same calibration run as in Fig. 4 except for using Eqs. (3) and (4) instead of Eq. (1). As expected, the modified FISH calibration evaluation (green line) levels out the dependence of WVMR on the cell pressure and therefore decreases the FISH uncertainty for high WVMR and low cell pressure considerably. When the calibration data are evaluated with the additional correction factor $X_{\mathrm{w}}$, the calibration factor $c_{\mathrm{k}}$ changes very little due to the detector dead time correction $\left(c_{\mathrm{k}}=0.00194\right.$ compared to $\left.c_{\mathrm{k}}=0.00209\right)$, whereas $f_{\mathrm{u}}$ is shifted from 3.47 down to 1.22 , which is close to the theoretical value of 1.15 . This calibration run demonstrates an extreme example of the outgassing effect; usually, the variations of $f_{\mathrm{u}}$ are smaller.

We checked all FISH data sets susceptible to changes when applying the modified FISH calibration evaluation. For atmospheric WVMR and pressure ranges, FISH data remain unchanged. Only during measurements at the AIDA chamber (see Sect. 5.2, Fig. 11), where experiments with high WVMR at low pressures and low WVMR at high pressures were performed, does the modified calibration equation become important.

\section{Data quality of FISH measurements - a survey}

During a measurement period, a crucial factor for accurate water vapor measurements with FISH, besides correct determination of the calibration coefficients, is the stability of the lamp and detector in between calibrations. Also, the calibration reference DP30 is crucial to the quality of the FISH water vapor measurements. Thus, a comprehensive check of the DP30 accuracy and precision (Sect. 4.1), the reproducibility of the FISH calibration (Sect. 4.2), as well as the resulting FISH measurement uncertainty, is given here. In Sect. 4.4 a new quality check procedure for high WMR in cirrus at high pressures $(400-500 \mathrm{hPa}$ ), unfavorable conditions for the Lyman- $\alpha$ technique, is presented.

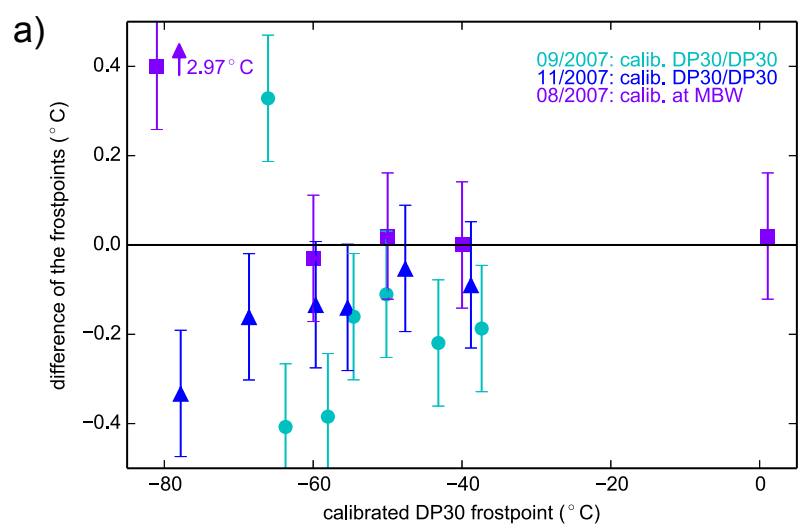

b)

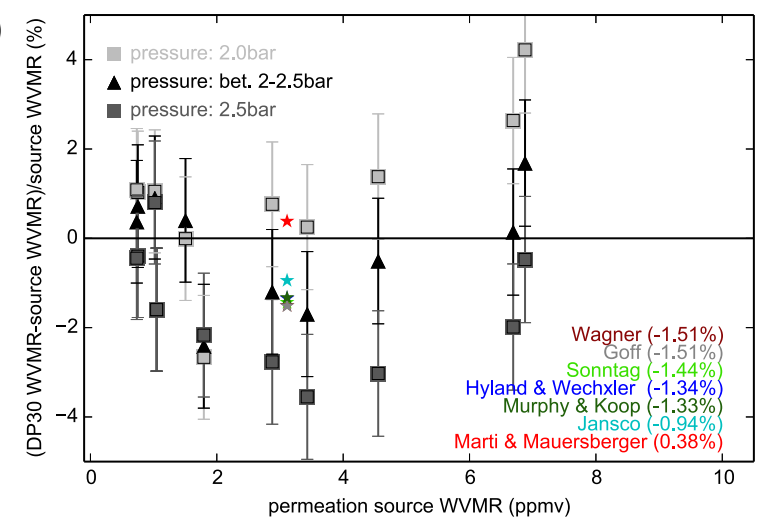

c)

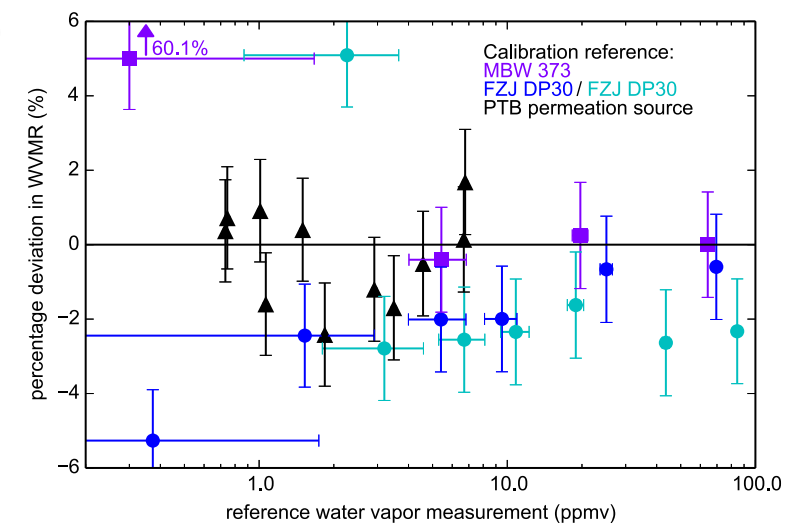

Figure 6. Reference hygrometer calibration: (a) difference of the measured frost points between the first Jülich DP30 frost-point hygrometer and a MBW reference frost-point hygrometer calibrated to a NPL standard (purple squares) or the second Jülich DP30 (dark blue triangles and light blue dots); (b) relative deviation of the DP30 WVMR measurement to the WVMR given by the permeation source (PTB, traceable to primary standard) for different pre-pressure levels and comparison of different saturation equilibrium approximations applied to the measured frost points (stars); (c) combination of the measurements of (a) and (b). 


\subsection{Accuracy of the calibration reference DP30}

The accuracy and precision of the DP30 is reviewed by three independent tests. First, the Jülich DP30 instruments are sent to the manufacturer to be re-calibrated against another reference frost-point hygrometer. This reference instrument is traceable to a British primary standard at the National Physical Laboratory (NPL). The result of one such comparison, performed in August 2007, is shown in Fig. 6a (purple squares). For frost-point temperatures between -60 and $-40^{\circ} \mathrm{C}$, the differences were negligible, i.e., below $\pm 0.1^{\circ} \mathrm{C}$. But, for the lowest temperature measurement at $-77.8^{\circ} \mathrm{C}$, the deviation between the DP30 and the reference instrument was $-2.97^{\circ} \mathrm{C}$, which corresponds to a difference of about $60 \%$ in water vapor mixing ratio. However, the validity of this data point is questionable as such a deviation could not be reproduced by any other procedure; thus, the data point will be ignored in further discussion.

A second check was performed by connecting both DP30 instruments to the Jülich calibration bench and by operating them in parallel at different frost points. Figure 6a (light blue dots and blue triangles) displays the comparisons carried out on 12 September 2007 and on 7 November 2007, respectively. For both measurements the second DP30 shows the tendency to measure about $0.1-0.4{ }^{\circ} \mathrm{C}$ lower frost-point temperatures than the DP30 that was sent to MBW. No major variability could be observed. This tendency results in 1-3\% underestimation of the respective water vapor mixing ratio. As a consequence, the first DP30 is used for standard calibrations, and the frost-point temperatures of the second DP30 are corrected for this constant offset.

For the third test, a permeation source was provided by the Physikalisch Technische Bundesanstalt (PTB), the German institute for metrology. This permeation source is a secondary standard calibrated to the PTB primary coulometric standard (http://www.ptb.de/cms/fachabteilungen/abt3/fb-32/ag-321/ sicherung-und-rueckfuehrung-von-gasfeuchtemessungen. html). The principle of the secondary standard is based on permeation of water through a solid material due to concentration differences. The permeability is influenced by the size and thickness of the membrane as well as the surrounding temperature and pressure. In this case the membrane was a PTFE tube embedded in a water-filled metal cylinder that then was placed in a water bath. Thus, for each experiment the temperature was held constant while the flow through the tube was varied to adjust the water vapor mixing ratio. The water vapor mixing ratio is calculated using Eq. (5). The coefficients $a, b, c$ and $d$ were determined via a calibration to the PTB primary standards.

$\mu=\frac{a+b \cdot T+c \cdot T^{2}+d \cdot T^{3}}{\text { Flow }}$

Dry synthetic air is further dried by a Hydrosorb cartridge (molecular sieve, drying the air to less than $20 \mathrm{ppbv}$ ) and then sent to the permeation source. After passing through the permeation source, the air, now having a well-defined water vapor mixing ratio, is delivered to the DP30 for calibration. A crucial parameter to calculate the source WVMR is the flow through the permeation source, which is set by a mass flow controller. This flow controller was calibrated against a soap film flowmeter and found to depend on the pressure at its input (pre-pressure).

Figure 6b (black triangles, measurement condition with pressure between 2 and 2.5 bar) displays the deviation in the water vapor mixing ratio of the DP30 measurement from the permeation source for different humidity levels. This deviation lies between -2 and $+2 \%$. The light and dark gray squares show how much the WVMR is affected if the prepressure is varied by a few tens of bar without considering the pressure dependence of the flow. This illustrates the lower and upper uncertainty of the permeation source. Thus, we estimate the uncertainty in WVMR to about $4 \%$ for this calibration setup due to the pressure dependence of the flow.

To convert frost-point temperatures measured by the DP30 into the corresponding WVMR, the equation to convert frostpoint temperature into saturation pressure by Sonntag et al. (1994) and the equation to convert saturation pressure into a water vapor mixing ratio (Wallace et al., 1976) are applied by default. A detailed discussion about different equilibrium approximations including a complex numerical solution for the thermodynamic equilibrium situation can be found in Murphy and Koop (2005). In Fig. 6b these different approximations all describing the equilibrium saturation pressure are plotted (stars) for one water vapor mixing ratio. A difference of about $3 \%$ between the extreme estimates is apparent, with the Sonntag approximation used for the DP30 falling into a range of $1 \%$ width where most of the estimates and especially the parameterization according to Murphy and Koop (2005) are centered. The conversion of the DP30 WVMR via the Sonntag equation therefore results in a maximum error of $1 \%$.

Figure $6 \mathrm{c}$ shows the combined results of all three methods. Summarizing the uncertainties, the previously estimated DP30 accuracy of 2-4\% is well reproduced with the comparison to the permeation source and all other tests described above.

\subsection{Reproducibility of FISH calibration}

Calibrations are normally performed after each flight or in regular intervals of a few days in order to detect potential drifts of the instrument sensitivity. Major changes of the calibration factors occur only when modifications, e.g., replacement of a detector, the $\mathrm{MgF}_{2}$ window or the mirror have been performed. For aircraft experiments, the calibration factors show only a very weak trend, which may be caused by dirtying of the cell and optical components. For clean chamber experiments such as AquaVIT-1 and 2, the calibration factors do not show an obvious trend (see Fig. 7). Thus, fre- 


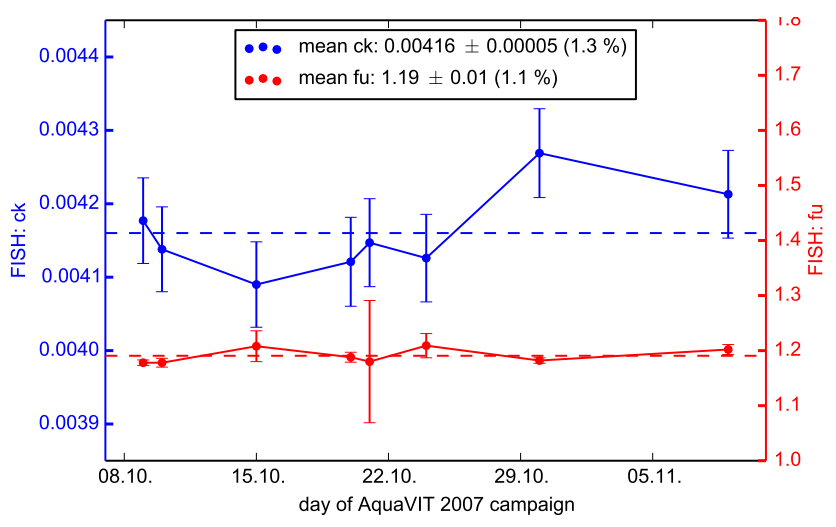

Figure 7. Time series for the calibration constants $c_{\mathrm{k}}$ and $f_{\mathrm{u}}$ during the AquaVIT-1 campaign evaluated with the enhanced calibration scheme.

quent calibrations, e.g., as during AquaVIT-1, can be used to test the reproducibility of the calibration and to increase their statistical significance. The standard deviation (SD) of $c_{\mathrm{k}}$ from the mean commonly is $\pm 1.5 \%$, and that of $f_{\mathrm{u}}$ is $\pm 2 \%$. Older measurements before AquaVIT-1 in 2007 have a larger uncertainty of $f_{\mathrm{u}}$ around $\pm 20 \%$ due to neglecting the outgassing effect described in Sect. 3 . These numbers can be used as a measure of the reliability of the calibration coefficient determination, not including the systematic uncertainties of the reference instrument (Sect. 4.1). Including the extended calibration procedure described in the previous section does not significantly influence the stability of the calibration constants during a measurement period (not shown here).

\subsection{FISH uncertainty}

Assuming high-flow aircraft conditions, the uncertainty of the measured WVMR is determined by propagation of the uncertainties in $c_{\mathrm{k}}$ and $f_{\mathrm{u}}$ in Eq. (1):

$\mathrm{d} \mu / \mu=\mathrm{d} c_{\mathrm{k}} / c_{\mathrm{k}}+\frac{f_{\mathrm{u}} \cdot N_{\mathrm{u}}}{N_{\mathrm{g}}-f_{\mathrm{u}} \cdot N_{\mathrm{u}}} \cdot \mathrm{d} f_{\mathrm{u}} / f_{\mathrm{u}}$.

The measurement uncertainties of the count rates $\left(N_{\mathrm{g}}\right.$ and $N_{\mathrm{u}}$ ) as well as the intensity $I_{0}$ are relatively small and, compared to the uncertainties in the calibration factors, negligible. The uncertainty in $f_{\mathrm{u}}$ mainly impacts the low WVMR range when $N_{\mathrm{g}}$ becomes the same order of magnitude as $N_{\mathrm{u}}$. As an example, for a WVMR of $1.2 \mathrm{ppmv}$ (the lowest WVMR we ever measured in the atmosphere; Schiller et al., 2009), typical values of $N_{\mathrm{g}}$ and $N_{\mathrm{u}}$ are 2500 and 500, respectively. With $f_{\mathrm{u}}=1.2$ an uncertainty $\mathrm{d} f_{\mathrm{u}} / f_{\mathrm{u}}=2 \%$ results in an additional uncertainty of the WVMR of $1 \%$ (second term in Eq. 6). As described above, FISH data prior to 2007, and especially 2001, should be considered with a higher uncertainty of the low WVMR of $5 \%$ in the light of our current procedures. For higher WVMR, the second term becomes negligible and $\mathrm{d} \mu / \mu$ is determined primarily by the uncertainty of $c_{\mathrm{k}}$.

To determine the overall measurement uncertainty, we have to add the different contributions from Sects. 4.1 to 4.3. For typical operational conditions, the combined total accuracy is $6-8 \%$ (6-10\% before 2007), mostly dependent on the stability of the continuous calibrations during the measurement campaign. This value was already reported by Zöger et al. (1999), but here we provide new evidence based on more accurate reference instruments and calibration procedures. In particular for low WVMR, we further have to consider the noise or detection limit, which is on the order of $0.15-0.40 \mathrm{ppmv}$ depending on instrument performance. Thus,

uncertainty $=$ accuracy + detection limit.

In summary, for mixing ratios of 1-4 ppmv, an absolute uncertainty of $0.3 \mathrm{ppmv}$ is a good first-order approximation for our measurements in the lower stratosphere, or 30 to $8 \%$ in relative terms over this range. From 4 to $1000 \mathrm{ppmv}$, an accuracy of 6-8\% is usually achieved. Around $1000 \mathrm{ppmv}$, further nonlinear effects determine the upper limit of the dynamical measurement range of FISH (see also next section). Due to increasing pressure or water vapor content, the measuring cell becomes optically thick, i.e., the Lyman- $\alpha$ radiation is more strongly absorbed by molecular oxygen and water vapor and therefore is no longer sufficient to illuminate the measurement volume. Thus, FISH is not operated at pressures above $500 \mathrm{hPa}$. For specific operation conditions, e.g., chamber experiments, we have to apply the flow, pressure and water vapor content-dependent correction described previously (see Sect. 3).

\subsection{Quality check procedure for high WVMRs}

FISH measures total water (gas phase + evaporated ice) by means of a forward looking inlet (see Sect. 2). In thick cirrus clouds at lower UT altitudes, i.e., at higher pressures (above $400 \mathrm{hPa}$ ) and temperatures (above $220 \mathrm{~K}$ ), high total WMR close to or more than 1000 ppmv can occur. Such conditions are unfavorable for the Lyman- $\alpha$ fluorescence technique since they lead to an increase in the optical thickness in the measuring cell and reveal the upper detection limit of FISH (see Sect. 4.2). Thus, these high total WMR in thick cirrus have to be carefully checked and rejected if the measurement is found to be invalid.

The extended high WVMR evaluation and the development of a rejection algorithm for invalid measurements are described in the following. From the calibrations, a relation for the fluorescence count rate $N_{\mathrm{g}}$, depending on pressure and the normalized inversed $I_{0}\left(\max \left(I_{0}\right) / I_{0}=I_{0}^{*}\right)$, can be derived. Figure $8 \mathrm{a}$ shows the relation for one calibration. The WVMRs (blue dots), different combinations of $I_{0}^{*}$ and $N_{\mathrm{g}}$, increase along the lines of specific pressure levels (black lines). The reason for using $I_{0}^{*}$ is to clearly distinguish the 
Table 1. List of all campaigns where FISH performance is compared to other instruments (for a list of instruments, see Table 2).

\begin{tabular}{|c|c|c|c|}
\hline Campaign & Location & Flight dates & Instrument intercomparison \\
\hline APE-THESEO 1999 & Seychelles, $5^{\circ} \mathrm{S}$, mid-latitude & 19 Feb, 04 Mar, 06 Mar, 09 Mar & FLASH \\
\hline THESEO/SOLVE 2000 & Kiruna $68^{\circ} \mathrm{N}$, Arctic & 27 Jan & HWV, JPH, NOAA-CMDL \\
\hline Envisat 2002 & Forli $44^{\circ} \mathrm{N}$, mid-latitude & $\begin{array}{l}13 \mathrm{Jul}, 18 \mathrm{Jul}, 22 \mathrm{Jul}, 08 \text { Oct, } 14 \text { Oct, } 17 \text { Oct, } \\
22 \mathrm{Oct}, 24 \text { Oct, } 28 \text { Oct }\end{array}$ & FLASH \\
\hline Euplex 2003 & Kiruna $68^{\circ} \mathrm{N}$, Arctic & $\begin{array}{l}15 \text { Jan, } 19 \text { Jan, } 23 \text { Jan, } 26 \text { Jan, } 06 \text { Feb, } 08 \text { Feb, } \\
09 \text { Feb, } 11 \text { Feb }\end{array}$ & FLASH \\
\hline Envisat 2003 & Kiruna $68^{\circ} \mathrm{N}$, Arctic & $28 \mathrm{Feb}, 02 \mathrm{Mar}, 08 \mathrm{Mar}, 12 \mathrm{Mar}, 16 \mathrm{Mar}$ & FLASH \\
\hline Troccinox 2005 & Aracatuba, $21^{\circ} \mathrm{S}$, tropics & $\begin{array}{l}27 \mathrm{Jan}, 01 \mathrm{Feb}, 04 \mathrm{Feb}, 08 \text { Feb, } 12 \text { Feb, } 15 \text { Feb, } \\
17 \mathrm{Feb}\end{array}$ & FLASH, AURA-MLS \\
\hline Marschals 2005 & Oberpfaffenhofen, $48^{\circ} \mathrm{N}$, mid-latitude & 07 Mar & FLASH \\
\hline Scout-O3 2005 & Darwin, $12^{\circ} \mathrm{S}$, tropics & $\begin{array}{l}07 \text { Nov, } 09 \text { Nov, } 11 \text { Nov, } 12 \text { Nov, } 23 \text { Nov, } \\
25 \text { Nov, } 29 \text { Nov, } 30 \text { Nov, } 30 \text { Nov }\end{array}$ & FLASH, AURA-MLS \\
\hline Amma 2006 & Ouagadougou, $12^{\circ} \mathrm{N}$, tropics & 04 Aug, 07 Aug, 11 Aug & FLASH, AURA-MLS \\
\hline Cirrus-III 2006 & Hohn, $54^{\circ} \mathrm{N}$, mid-latitude & 24 Nov, 28 Nov, 29 Nov & MOZAIC sensor \\
\hline AquaVIT-1 2007 & Karlsruhe, $49^{\circ} \mathrm{N}$ & cf. Fahey et al. (2014) & $\begin{array}{l}\text { APicT, CFH, FLASH, HWV, JLH and other (cf. } \\
\text { Fahey et al., 2014) }\end{array}$ \\
\hline Reconcile 2010 & Kiruna $68^{\circ} \mathrm{N}$, Arctic & $\begin{array}{l}17 \text { Jan, } 22 \text { Jan, } 24 \text { Jan, } 25 \text { Jan, } 28 \text { Jan, } 30 \text { Jan, } \\
02 \text { Feb, } 02 \text { Mar, } 02 \text { Mar }\end{array}$ & FLASH \\
\hline MACPEX 2011 & Houston, $29^{\circ} \mathrm{S}$, mid-latitude & cf. Rollins et al. (2014) & $\begin{array}{l}\text { CIMS, HWV, DLH, CFH and other (cf. Rollins } \\
\text { et al., 2014) }\end{array}$ \\
\hline TACTS/ESMVal 2012 & Oberpfaffenhofen, $48^{\circ} \mathrm{N}$, mid-latitude & $13 \mathrm{Sep}$ & HAI (cf. Rolf et al., 2015) \\
\hline Airtoss 2013 (DENCHAR) & Hohn, $54^{\circ} \mathrm{N}$, mid-latitude & $\begin{array}{l}07 \text { May, } 08 \text { May, } 29 \text { Aug, } 30 \text { Aug, } 03 \text { Sep, } \\
04 \text { Sep, } 05 \text { Sep }\end{array}$ & WASUL, IHD, WVSS2 \\
\hline AquaVIT-2 2013 & Karlsruhe, $49^{\circ} \mathrm{N}$ & 15 Apr, 16 Apr, 17 Apr, 18 Apr, 19 Apr & $\begin{array}{l}\text { APicT, HWV, NOAA-TDL, WASUL, CFH, } \\
\text { HAI, WVSS2 }\end{array}$ \\
\hline ML-Cirrus 2014 & Oberpfaffenhofen, $48^{\circ} \mathrm{N}$, mid-latitude & $\begin{array}{l}26 \mathrm{Mar}, 27 \mathrm{Mar}, 29 \mathrm{Mar}, 01 \mathrm{Apr}, 03 \mathrm{Apr} \\
04 \mathrm{Apr} \_1,04 \text { Apr_2, } 07 \mathrm{Apr}, 11 \mathrm{Apr}, 13 \mathrm{Apr}\end{array}$ & SHARC \\
\hline
\end{tabular}

APE-THESEO: Airborne Platform for Earth observation - THird European Stratospheric Experiment on Ozone; SOLVE: SAGE III Ozone Loss and Validation Experiment; Envisat: Envisat validation campaign; Euplex: EUropean Polar stratospheric cloud and Lee-wave EXperiment; Troccinox: Tropical Convection, Cirrus, and Nitrogen Oxides Experiment; Marschals: Marschals validation campaign; Scout-O3: Stratospheric-Climate links with emphasis On the Upper Troposphere and lower stratosphere; Amma: African Monsoon Multidisciplinary Analyses; Cirrus-III: Cirrus 3 campaign; AquaVIT-1: Aqua Validation and Instrument Tests 1; Reconcile: with emphasis On the Upper Troposphere and lower stratosphere; Amma: African Monsoon Multidisciplinary Analyses; Cirrus-III: Cirrus 3 campaign; AquaVIT-1: Aqua Validation and Instrument Tests 1; Reconcile: Transport And Composition in the UT/LS/Earth System Model Validation; Airtoss (DENCHAR): Development and Evaluation of Novel Compact Hygrometer for Airborne Research; AquaVIT-2: Aqua Validation and Transport And Composition in the UT/LS/Earth Systen

high WVMR at different pressure levels. From the calculated function (black lines), depending only on $I_{0}^{*}$ and pressure, the corresponding $N_{\mathrm{g}}$ along one pressure level can be calculated. Thus, it is possible to derive a theoretical count rate $\left(N_{\mathrm{g}, \text { calc }}\right)$ from the $I_{0}$ intensity measurement and the corresponding cell pressure for measurement flights. When the measuring cell becomes optically thick due to high pressure and/or high WVMR, the measured $N_{\mathrm{g}}$ no longer fits the measured lamp intensity $I_{0}$.

Figure $8 \mathrm{~b}$ shows the time series of a flight during the MLCirrus campaign. If the measured count rate $N_{\mathrm{g}}$ (green) deviates more than $30 \%$ from $N_{\mathrm{g} \text {,calc }}$ (black), we define a mismatch of $I_{0}$ and $N_{\mathrm{g}}$ and reject the data point $\left(\mathrm{H}_{2} \mathrm{O}\right.$ out, red). The first increase of WVMR, caused by a cirrus cloud at
12:55:05 to 12:55:20 UTC, looks correct if considering only the WVMR. However, $N_{\mathrm{g}}$ and the WVMR are already too low for the detected $I_{0}$. That means the measurement cell has started to become optically thick and the corresponding WVMRs have to be rejected. The second cloud in Fig. $8 \mathrm{~b}$ at 12:55:40 to 12:55:50 UTC, caused an enhanced optical thickness of the cell (very low $N_{\mathrm{g}}$ compared to $I_{0}$ ), which resulted in decreased instead of increased WVMR. Thus, these values are also rejected. However, the enhanced values to the right of this cloud correspond to a thinner cirrus that can be detected with FISH.

From the extended high WVMR evaluation it follows that the upper detection limit of FISH is not clearly defined. A first estimate for the upper detection limit is 1000 ppmv. 
Table 2. List of instruments compared with FISH.

\begin{tabular}{llll}
\hline Acronym & Instrument technique & Platform & Reference \\
\hline 1 APicT & Open path dTDLAS $(1.4 \mu \mathrm{m})$ & AIDA & Fahey et al. (2014) \\
$2 \mathrm{CFH}$ & Frost-point & Balloon, AIDA & Vömel et al. (2007) \\
$3 \mathrm{CIMS}$ & Chemical Ionization Mass Spectrometer & WB-57 & Thornberry et al. (2013a) \\
$4 \mathrm{DLH}$ & Open path TDLAS $(1.4 \mu \mathrm{m}, 2 \mathrm{f}$ detection) & WB-57 & Diskin et al. (2002) \\
$5 \mathrm{FLASH}$ & Lyman- $\alpha$ & Geophysica, AIDA & Sitnikov et al. (2007) \\
$6 \mathrm{FPH}$ & Frost-point & Ballon & Hurst et al. (2011) \\
$7 \mathrm{HAI}$ & Open and closed path dTDLAS $(1.4$ and $2.6 \mu \mathrm{m})$ & HALO, AIDA & Buchholz (2014) \\
$8 \mathrm{HWV}$ & Lyman- $\alpha$ & WB-57, AIDA & Weinstock et al. (2009) \\
$9 \mathrm{JLH}$ & Open path TDLAS $(1.4 \mu \mathrm{m}, 2 \mathrm{f}$ detection) & WB-57, AIDA & May (1998) \\
$10 \mathrm{LMD}-\mathrm{CNRS}$ & Frost-point & Ballon, Falcon & Ovarlez (1991) \\
$11 \mathrm{MLS}$ & Microwave Limb Sounder, satellite & EOS Aura & Waters et al. (2006) \\
$12 \mathrm{MOZAIC} \mathrm{sensor}$ & Capacitive sensor & Falcon, Learjet & Helten et al. (1998); Neis et al. (2015) \\
$13 \mathrm{NOAA-CMDL}$ & Frost-point & Balloon, ER-2 & Mastenbrook (1980) \\
$14 \mathrm{NOAA}-\mathrm{TDL}$ & Closed path TDLAS $(2.6 \mu \mathrm{m}, 2 \mathrm{f}$ detection) & Global Hawk, AIDA & Thornberry et al. (2013b) \\
$15 \mathrm{SHARC}$ & Closed path dTDLAS $(1.4 \mu \mathrm{m})$ & HALO & - \\
16 WASUL & Photoacoustic & Learjet, AIDA & Tátrai et al. (2014) \\
\hline
\end{tabular}

1: AIDA PCI in-cloud TDL, KIT, Germany; 2: Cryogenic Frostpoint Hygrometer (a modification of the NOAA FPH), NOAA, USA; 3: Chemical Ionization Mass Spectrometer, NOAA, USA; 4: Diode Laser Hygrometer, JPL, USA; 5: Fluorescent airborne stratospheric hygrometer, CAO, Russia; 6: Frost Point Hygrometer of the National Oceanic and Atmospheric Administration, NOAA, USA; 7: Hygrometer for Atmospheric Investigations, PTB/FZJ, Germany; 8: Harvard Water Vapor, Harvard, USA; 9: Jet Propulsion Laboratory Laser Hygrometer, JPL, USA; 10: Laboratoire de Météorologie Dynamique (LMD) of the Centre National De Recherche Scientifique, France; 11: Microwave Limb Sounder, JPL, NASA, USA; 12: Measurements of OZone, water vapour, carbon monoxide and nitrogen oxides by in-service AIrbus airCraft, FZJ, Germany; 13: Climate Monitoring and Diagnostics Laboratory of the National Oceanic and Atmospheric Administration, NOAA, USA; 14: National Oceanic and Atmospheric Administration - Tunable Diode Laser; 15: Sophisticated Hygrometer for Atmospheric Research, DLR, Germany; 16: WASUL-Hygro, Hilase, Hungary.

Table 3. List of all FISH in situ comparisons (for a list of the instruments, see Table 2).

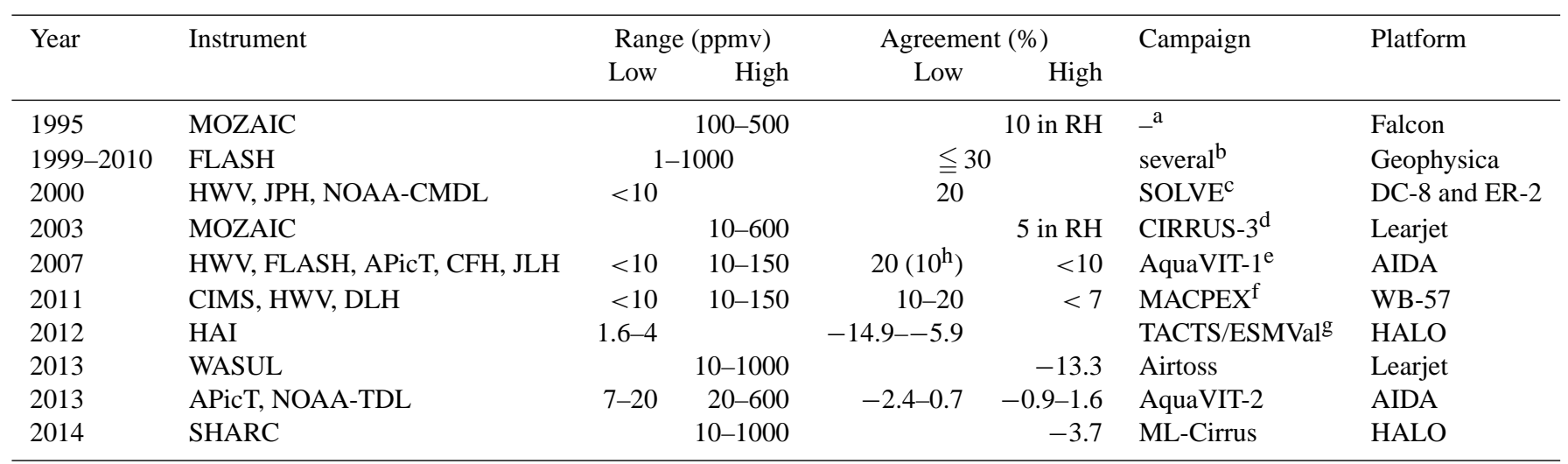

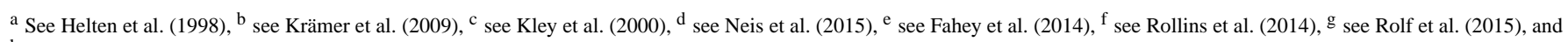

$\mathrm{h}$ new extended calibration evaluation.

For thick cirrus at pressures below $300 \mathrm{hPa}$, no data have to be rejected. However, at pressures above $300 \mathrm{hPa}$, the number of rejected data increases with pressure; this varies with the type of observed cirrus. This behavior was first observed during MACPEX in 2011, where very dense and thick cirrus were observed. However, the cirrus measurements in previous campaigns, published in Schiller et al. (2008) and Krämer et al. (2009), were observed either at higher altitudes (lower pressures) or with distinct lower total WMRs, and are therefore not considered to be invalid measurements.

\section{FISH intercomparison measurements - a summary}

High accuracy and measurement stability in a laboratory environment do not necessarily imply the same performance in the field. Especially for in situ water vapor measurements on board aircraft and balloons, operation and sampling conditions potentially influence the measurements. One way to cross-check the in-flight performance is to compare the FISH measurements to other spatially and temporally collocated in situ or satellite-based water vapor measurements. Since water vapor measurements are valuable for a wide variety of 

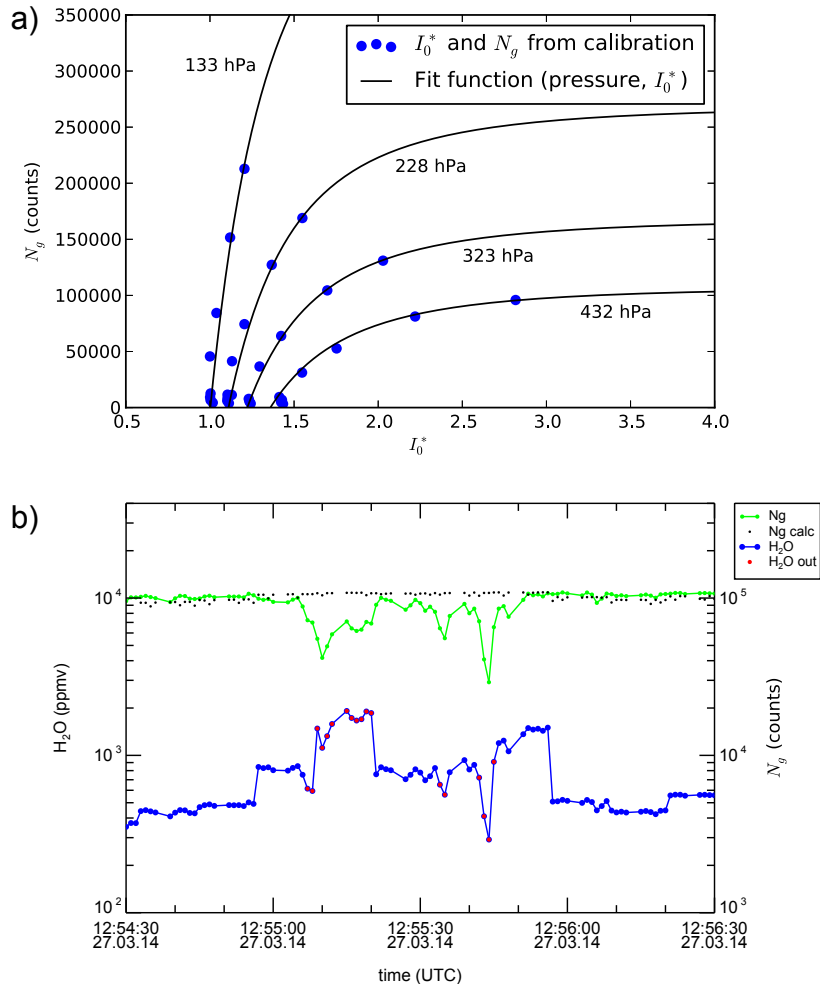

Figure 8. Quality check procedure for high WVMRs: (a) correlation between $I_{0}^{*}$ and $N_{\mathrm{g}}$ (calibration data, blue dots) with pressuredependent fit function (black lines); (b) time series of calculated count rate $\left(N_{\mathrm{g}, \text { calc }}\right.$, black dots $)$, measured count rate $\left(N_{\mathrm{g}}\right.$, green dots), water vapor (blue dots), and rejected water vapor $\left(\mathrm{H}_{2} \mathrm{O}\right.$ out, red dots) during one flight of ML-Cirrus.

research in the UT/LS region, other hygrometers were often operated in parallel to FISH, which provided opportunities for instrument intercomparisons (see Table 1). In addition, FISH participated in a number of projects where flight patterns and aircraft instrumentation were specifically designed to allow instrument intercomparisons and instrument performance tests. FISH also participated in systematic tests of the instrumentation in the laboratory such as the AIDA cloud chamber, where various measurement conditions including clouds can be simulated (Fahey et al., 2014). Note that such comparisons are not absolute proof of the high accuracy of FISH but nevertheless strengthen the confidence in the FISH performance. An overview of all campaigns allowing comparisons of FISH to other hygrometers is given in Table 1 and a list of all instruments compared with FISH can be found in Table 2.

\subsection{In-flight performance and aircraft intercomparisons}

During multiple FISH research flights, a number of possibilities arose to compare the FISH performance to other hygrometers measuring UT/LS water vapor (see Tables 1$3)$. This set of comparisons includes flights where other in situ hygrometers were flown spatially and temporally coincident with FISH but not on the same platform. Such a set of comparisons dating back to the early FISH operation period before 2000 is mentioned in Kley et al. (2000), where it was found that the FISH measurements, the frost-point hygrometer LMD and the capacitive sensor MOZAIC agreed within $10 \%$ in relative humidity (RH). FISH water vapor measurements during THESEO and SOLVE ${ }^{1}$ also matched with those of the high-precision Harvard Lyman- $\alpha$ hygrometer HWV, the Jet Propulsion Laboratory (JPL) laser hygrometer JLH and the frost-point hygrometer NOAA-CMDL within $1 \mathrm{ppmv}$, although a systematic low offset with respect to JLH and a systematic high offset with respect to NOAACMDL was observed.

The most extensive data set for in situ comparison however was obtained on board the high-altitude aircraft Geophysica, where both the FISH total water instrument and the FLASH Lyman- $\alpha$ hygrometer (Sitnikov et al., 2007) flew. The relative difference of the two instruments is of specific interest as the combination of FISH and FLASH measurements is used to derive the ice water content IWC (Schiller et al., 2008) and relative humidity inside and outside of clouds (Krämer et al., 2009). Thus, a review of all flights in clear sky conditions, indicated by relative humidities lower than $80 \%$, is summarized in Fig. 9 (see also Tables 1-3). The graph shows the percentage difference in clear sky water vapor content in dependence on the flight pressure level. The colors indicate the frequency of occurrence of the deviations for the entire data set. Although FISH and FLASH differ by up to $100 \%$ in extreme cases, values smaller than $30 \%$ are most frequent. There seems to be no systematic offset between the two instruments. A slight trend of FISH measuring slightly higher values in high-pressure areas might be due to imperfect rejection of cloudy air masses. Otherwise, no correlation of the relative difference between the two instruments with other atmospheric variables (such as relative humidity or temperature) was found.

Beyond research flights, the MACPEX campaign with the NASA WB-57 research aircraft (Rollins et al., 2014) provided an opportunity for an intensive in situ hygrometer intercomparison. Within the combined instrument uncertainties, FISH measured slightly drier water vapor content $(\approx 10-20 \%$ or $\approx 0.6 \mathrm{ppmv}$ below $10 \mathrm{ppmv})$ in comparison to most of the Ionization Mass Spectrometer (CIMS) with in-flight calibration (Rollins et al., 2014). The slight

\footnotetext{
${ }^{1}$ Note here that all abbreviations of campaigns and instruments are listed in Tables 1 and 2.
} 


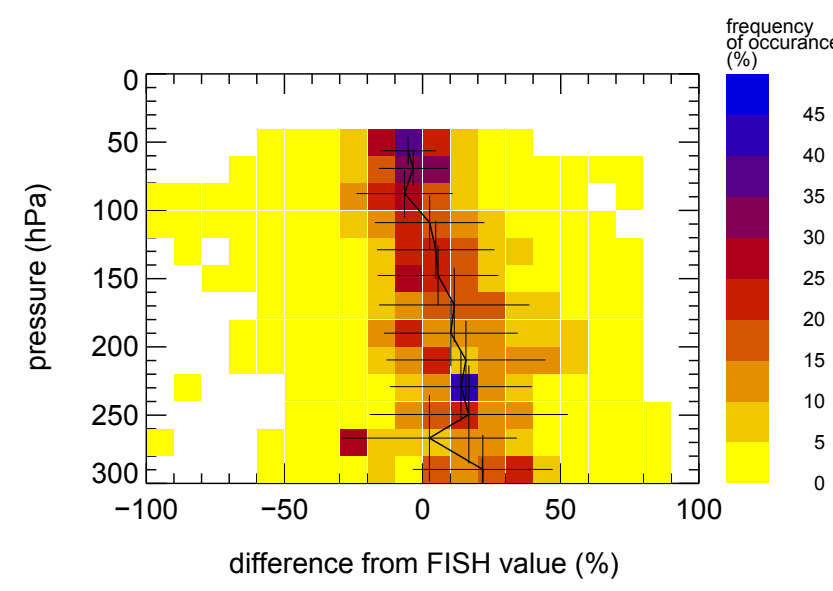

Figure 9. Relative difference between FISH and FLASH water vapor content outside of clouds for all coincident flights between 1999 and 2012 in dependence on pressure (51563 data points $=14.3$ flight hours). Clear sky conditions are defined by relative humidities lower than $80 \%$.

dry bias of FISH with respect to HWV (avg. 0.63 ppmv), CIMS (avg. 0.77 ppmv), and DLH (avg. 0.55 ppmv) during MACPEX was consistently observed, even when applying the newly developed FISH calibration scheme described in detail in Sect. 3.2. However, both frost-point hygrometers (FPH and $\mathrm{CFH}$ ) operated on a balloon during MACPEX agreed quite well with the FISH $(\approx 1 \%$ or $\approx 0.05 \mathrm{ppmv}$ at the 4 ppmv level) (Rollins et al., 2014). The reason for the difference between the frost-point-based instruments (FPH, $\mathrm{CFH}$ and also FISH) and the other instruments on board the WB-57 (e.g., CIMS, HWV, DLH) remains unclear.

On board the new German research aircraft HALO, FISH was operated in 2012 side by side with the new hygrometer HAI (Buchholz, 2014) during the combined campaigns TACTS (Engel et al., 2013) and ESMVal (Schlager et al., 2014). In the lower range from $4 \mathrm{ppmv}$ down to $1.6 \mathrm{ppmv}$ HAI reveals a fairly good mean relative deviation (MRD) between -14.9 and $-5.9 \%$ during a flight in the Antarctic vortex (for details, see Rolf et al., 2015).

Another systematic in situ hygrometer intercomparison was embedded in the Airtoss campaign, which took place in 2013 on board a Learjet. The intercomparison was part of the Eufar DENCHAR project (Smit et al., 2014). This project is dedicated to the development, testing and comparison of new, compact instruments measuring WVMR above 10 ppmv. In the top panel of Fig. 10 we show a comparison between FISH and the WASUL photoacoustic instrument (red dots, details in Tátrai et al., 2014). A generally good agreement of about $-13.3 \%$ for WMVR up to 1000 ppmv was found for WASUL. During the ML-Cirrus mission with the HALO aircraft, the TDL hygrometer SHARC measured gas-phase MR parallel to the total water measurements of FISH. In the bottom panel of Fig. 10 SHARC and FISH measurements outside of clouds from one flight (13 April 2014) are shown and re-
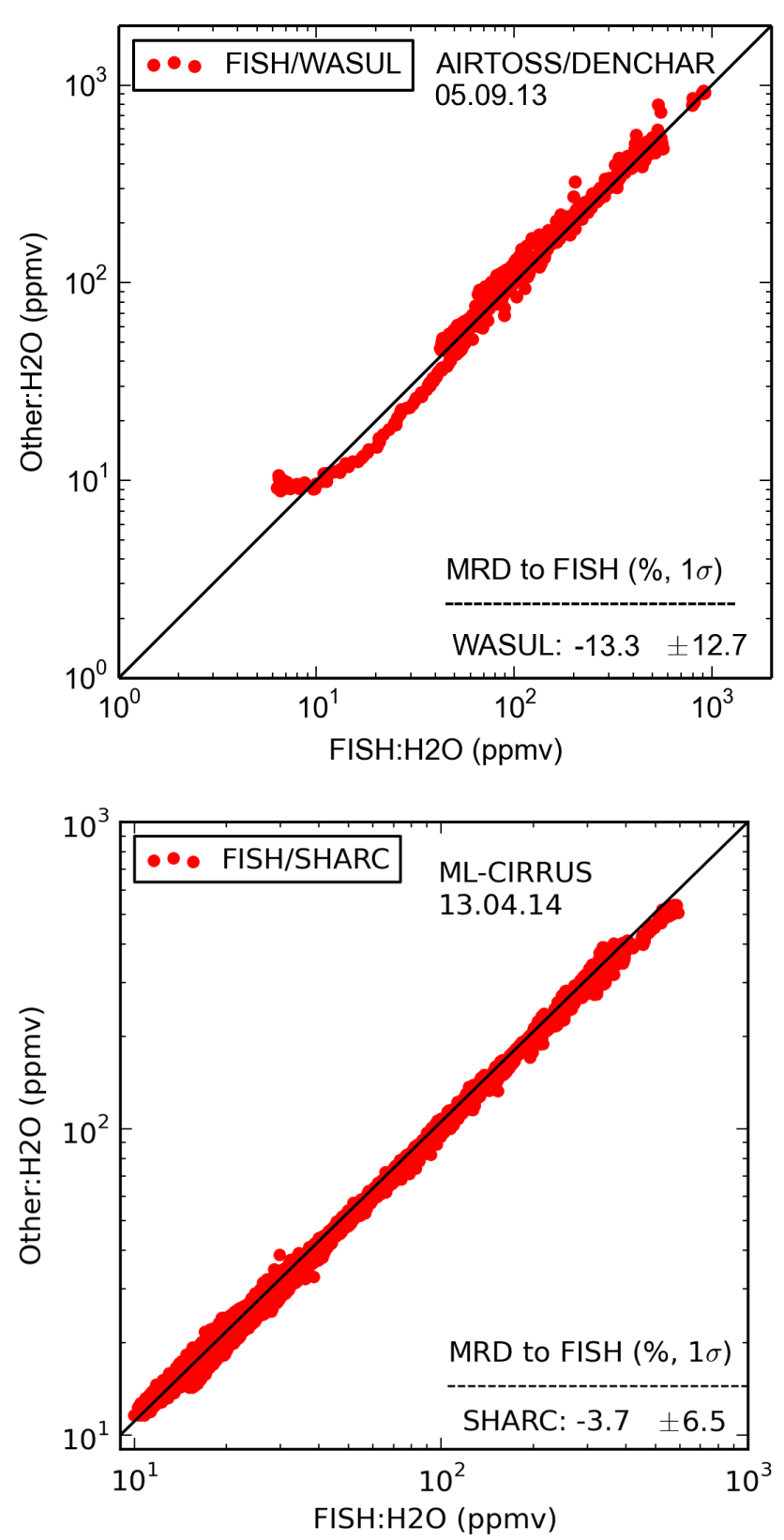

Figure 10. Scatterplot of FISH-WVMR vs. WASUL (red) during Airtoss/DENCHAR 2013 (top panel) and SHARC during MLCirrus 2014 (bottom panel). The mean relative deviation (MRD) with SD from FISH is given for each individual instrument.

veal a very good agreement (MRD) of below $-3.7 \%$ ranging from 10 to 600 ppmv.

In general, the in situ aircraft intercomparisons are within their combined instrument uncertainties.

\subsection{Laboratory intercomparisons}

Starting in 2007, FISH participated in two laboratory intercomparison experiments: AquaVIT-1 (Fahey et al., 2014) 

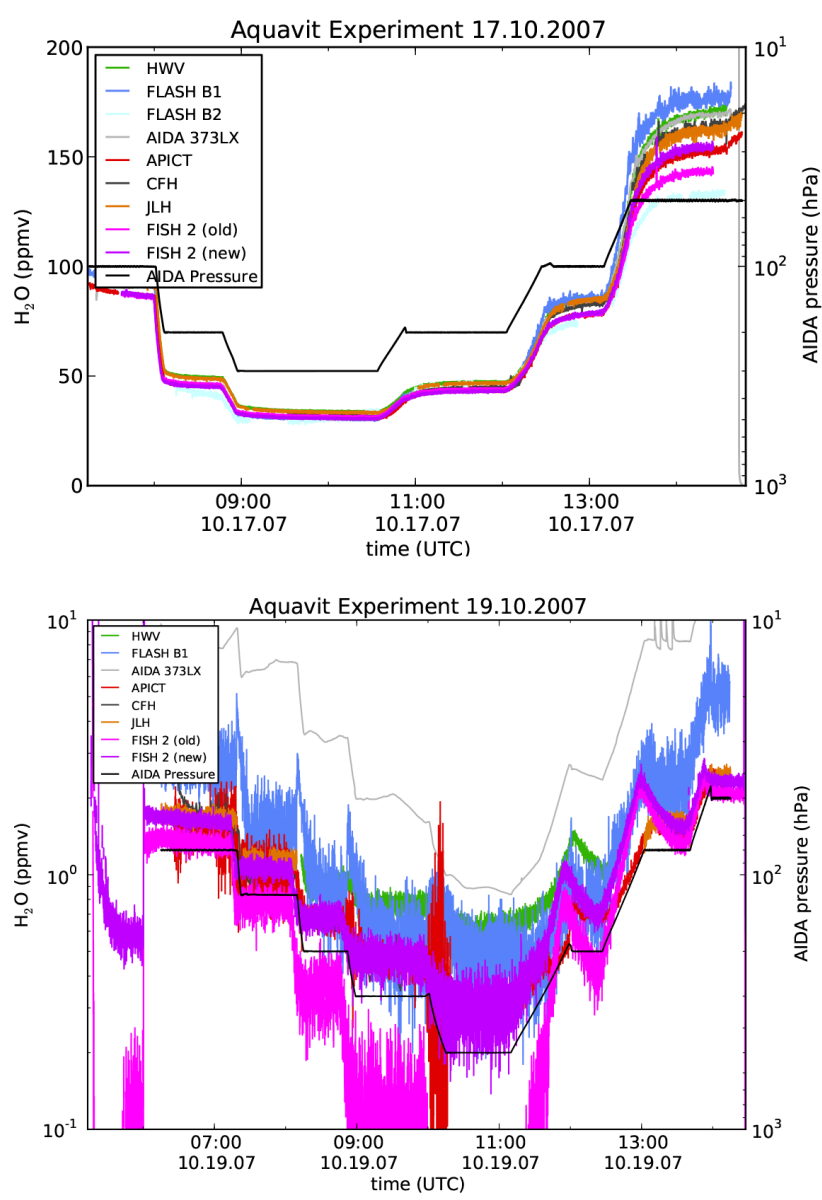

Figure 11. Time series of water vapor measurements at the AIDA chamber in Karlsruhe during the AquaVIT campaign in 2007.

and AquaVIT-2. In this context, the instruments were systematically tested under simulated natural operation conditions, but extreme environmental and water vapor settings were also addressed. HWV, FLASH, APicT, WASUL, CFH (a modification of the NOAA FPH) and JLH were part of AquaVIT-1, while APicT, HAI, WASUL and the NOAATDL participated in AquaVIT-2 (more information on the instruments is given in Tables 1-2).

In comparison to the systematic and non-systematic airborne intercomparisons shown in the previous section, the deviations of water vapor observed by instruments HWV, FLASH, APicT, CFH and JLH to FISH were generally smaller during the AquaVIT-1 static intercomparison periods (see Table 3 ). For the laboratory experiments in the 10 to 150 ppmv range, Fahey et al. (2014) report variations in measured water vapor content of about $\pm 10 \%$ around a mean value that was derived from the core subset of the participating instruments due to the lack of an appropriate reference instrument. Thus, the deviations between FISH and the other hygrometers mostly fell within the combined instrument uncertainties for that water vapor range. Fahey et al.
(2014) also found a "fair" agreement of $\pm 20 \%$ for water vapor contents between 1 and 10 ppmv, slightly larger than the combined uncertainties of the instruments. However, below $1 \mathrm{ppmv} \mathrm{H}_{2} \mathrm{O}$, the percentage difference of measured water vapor detected by the different instruments increased ( $\mathrm{Fa}$ hey et al., 2014). The value of these sub 1 ppmv AIDA measurements is questionable when considering the atmospheric measurements, since mixing ratios this low at the high pressures used in AIDA never occur in the atmosphere, and as such are outside the design parameters for the in situ instrumentation.

As an example of the systematic intercomparison experiments during AquaVIT-1, Fig. 11 shows two time series of water vapor measurements made with the instruments listed above. FISH measurements are displayed twice, first using the standard calibration Eq. (1), and second applying the extended calibration Eqs. (3) and (4) described in Sect. 3.2, which considers the outgassing of the cell in determining the calibration factors.

The upper panel in Fig. 11 shows a time series for mixing ratios up to $150 \mathrm{ppmv}$, where the largest percentage differences occur at the highest mixing ratios and low chamber pressure. Here, the extended calibration equations increases FISH (light purple) by about $6 \%$ (dark purple) and shifts it closer to the AIDA hygrometer APicT. This hygrometer, though not used as an absolute standard during AquaVIT-1, provided data closest to the mean of all core instruments for almost all water vapor ranges (Fahey et al., 2014). Thus, the relative differences of FISH to the other hygrometers for high mixing ratios become similar as for other AquaVIT-1 water vapor ranges, i.e., $1-10 \mathrm{ppmv}$.

For the mixing ratio range below $1 \mathrm{ppmv}$, the bottom panel of Fig. 11 shows how the FISH data are corrected for outgassing, again shifting FISH by $10-15 \%$ and thus closer to APicT. Hence, some of the FISH data points in the AquaVIT experiment shown in Fahey et al. (2014), in particular those for the lowest mixing ratios below $1 \mathrm{ppmv}$ and those at the highest mixing ratios, are revised, leading to an agreement of about $10 \%$ with the other hygrometers, which is consistent with those obtained in the 1-20 ppmv range.

The extended calibration evaluation scheme is also applied to the FISH data collected during AquaVIT-2 in 2013. Here, the mean relative deviation (MRD) between FISH, the reference instrument APicT and the NOAA-TDL is between -2.4 and $0.7 \%$ in the range of 7 up to $20 \mathrm{ppmv}$ and even better between -0.9 and $1.6 \%$ in the upper range from 20 to 600 ppmv (see Fig. 12 and Table 3). Altogether, the generally better agreement of FISH during laboratory intercomparisons using the extended calibration evaluation scheme is demonstrated from Figs. 11 and 12.

\subsection{Satellite intercomparisons: FISH - Aura MLS}

Water vapor in the UT/LS region is not only measured by in situ instrumentation on board aircraft and balloons, 

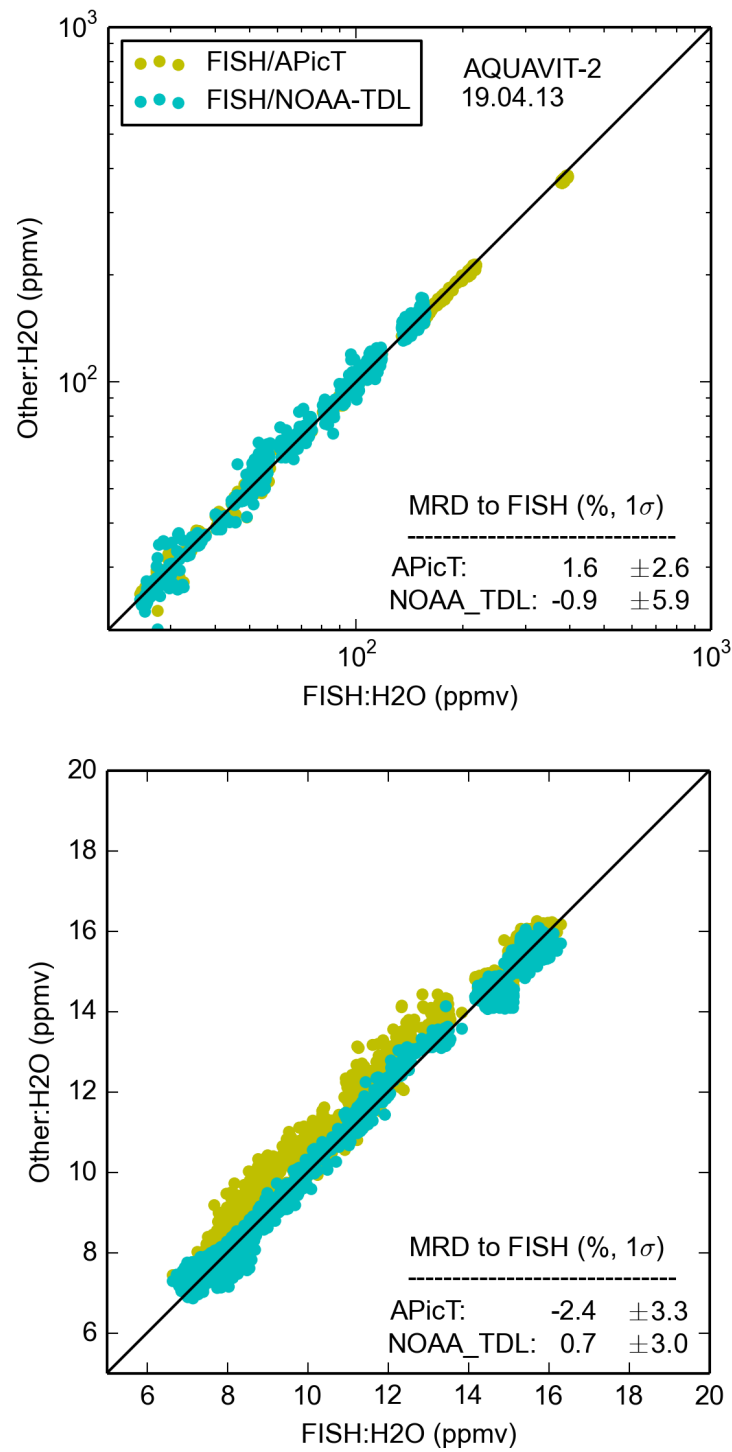

Figure 12. Scatterplot of WVMR during AquaVIT-2 (19.04.2012); top: WVMR 20-1000 ppmv; bottom: zoom for WVMR 7-20 ppmv. Mean relative deviation (MRD) to FISH is given for each individual instrument.

but is also monitored by satellite-based instruments. In the past, whenever possible, FISH measurements were readily taken to validate these satellite-based hygrometers (Thomason et al., 1994; Kanzawa et al., 2002; Offermann et al., 2002; Lumpe et al., 2006; Kiemle et al., 2008; Müller et al., 2008; Milz et al., 2009; Wetzel et al., 2013).

Figure 13 demonstrates the comparison of the Microwave Limb Sounder (MLS) (Lambert et al., 2007; Read et al., 2007) installed on the NASA Aura satellite with respect to the FISH instrument. For the comparison, all MLS measurements within $12 \mathrm{~h}, 5^{\circ}$ latitude, and $2^{\circ}$ longitude from a FISH vertical profile flight location during Troccinox, Amma, Scout, Reconcile and MACPEX (see Table 1) were

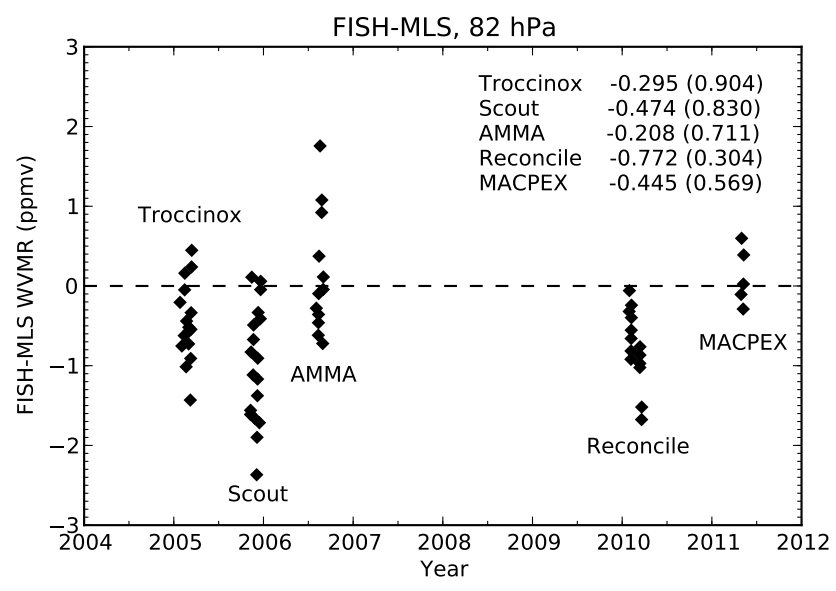

Figure 13. Comparison of FISH with MLS (Microwave Limb Sounder on the Aura satellite) for different aircraft campaigns. Mean deviation with respective SD for each campaign is given in the upper right. There are 25 matches for Troccinox, 23 for Scout, 16 for AMMA, 29 for Reconcile and 5 for MACPEX, and matches are within $12 \mathrm{~h}, 5^{\circ}$ latitude and $2^{\circ}$ longitude.

considered. The vertical resolution for MLS water vapor in the lower stratosphere is on the order of $3 \mathrm{~km}$. Because of that, vertical averaging kernels need to be applied to adequately compare with the extremely high vertical resolution aircraft data. To do this, we need aircraft profiles that encompass the $3 \mathrm{~km}$ range around the pressure level of interest. For this reason, we are only able to do the FISH-MLS comparisons at the $82 \mathrm{hPa}$ level. For each campaign, a mean value and a SD of the difference are calculated from all comparable FISH-MLS profiles (see Fig. 13). Differences are between $\pm 2 \mathrm{ppmv}$ at the low water vapor concentrations found in the stratosphere (typically less than $10 \mathrm{ppmv}$ ). The mean differences FISH-MLS for the different campaigns range from -0.2 to $-0.5 \mathrm{ppmv}-$ with MLS having slightly higher values - and are therefore approximately $\leq 10 \%$ at the 4 ppmv stratospheric level. An exception is the Reconcile campaign, where MLS has a larger deviation with moister values of about 0.7 ppmv compared to FISH. This slightly higher value was observed at high latitudes during the Reconcile campaign, and appears to be a MLS retrieval artifact (S. Davis, personal communication, 2014). Similar deviations of -0.2 to $-0.7 \mathrm{ppmv}$ are found for all campaigns at the $100 \mathrm{hPa}$ level (not shown). Overall, Fig. 13 demonstrates the excellent agreement between FISH and MLS water vapor measurements over the 6-year period from 2005 to 2011.

\section{Summary}

Since 1996, the Lyman- $\alpha$ fluorescence hygrometer FISH has been deployed on balloons and multiple aircraft platforms, as well as at the AIDA chamber during numerous campaigns. The large data set, compiled over this decade-long interval, 
affords a unique perspective from which to evaluate the performance of FISH. We have now reassessed the calibration, measurement, and data evaluation procedures for FISH as well as its performance on aircraft and in the laboratory.

First, the calibration reference frost-point mirror instrument (DP30) was compared to two different traceable standards (PTB and NPL), confirming a maximum uncertainty of $\pm 4 \%$ for the water mixing ratio. Second, we introduced a modified calibration evaluation that now accounts for high WVMRs together with low pressures and low WVMRs together with high pressures (AIDA chamber conditions), which are typically not encountered by FISH during atmospheric sorties. With the modified calibration evaluation, the agreement of FISH with the other hygrometers improved for these special conditions from $\pm 20 \% @<10$ ppmv and $10 \% @>100$ ppmv reported by Fahey et al. (2014) to $\pm 10 \%$ and $<10 \%$, respectively. Furthermore, a quality check procedure has been developed that accounts for invalid total water measurements that can occur in thick cirrus clouds at high pressures of about $400-500 \mathrm{hPa}$.

During the last two decades, FISH has had many opportunities to compare with other in situ hygrometers. In fact, some campaigns were partly be dedicated to assessing hygrometer performance, like the MACPEX campaign with the WB-57 in 2011 (Rollins et al., 2014), Airtoss in 2013 on board a Learjet and the AIDA intercomparisons AquaVIT1 in 2007 (Fahey et al., 2014) as well as AquaVIT-2 in 2013. An encouraging result of all the intercomparisons is that the agreement between the hygrometers has improved over the years from overall up to $\pm 30 \%$ or more to about \pm 5 $20 \% @<10$ ppmv and to $\pm 0-15 \% @>10$ ppmv.

In addition to the in situ intercomparisons, FISH was also compared to the remote sensing instrument MLS on-board the Aura satellite during five airborne campaigns between 2005 and 2011. The agreement between both instruments was found to be better than $10 \%$ at the 4 ppmv level, which can also be seen as a validation of the satellite instrument.

This study reflects the process to better characterize the FISH hygrometer and to achieve even higher confidence in the UT/LS water vapor measurement. Similar work could be done also by other instrument groups to resolve the improved (but still existing) discrepancies between instruments in the UT/LS water vapor concentration range. Future work for FISH is to better quantify the zero line of our system to evaluate if there have been unknown effects so far. Finally, an Allan deviation analysis could be done to quantify on which timescales a long-term drift could dominate over white noise properties.

Summing up, the intense review of the FISH calibration technique and its validation against traceable reference water standards as well as laboratory, in-flight and remote sensing instrumentation demonstrate the ability of FISH to precisely and reliably measure water vapor in the UT/LS.

\section{Dedication to Dr. Cornelius Schiller}

This work is dedicated to our highly appreciated and valued colleague and mentor Dr. Cornelius Schiller. Without him, this work, and especially the instrumentation described here, would not have reached its high level of quality. He devoted all his efforts towards improving the FISH (see Fig. 1) instrument, making it one of the leading instruments for measuring the low water vapor content of the stratosphere. His efforts contributed to developing a better understanding of the transport mechanisms and variability of water vapor in the UT/LS. With his death, we lost not only a treasured colleague and friend, but a also mentor and a paragon in the instrumental community.

Acknowledgements. We are grateful for the support of the technical staff at the AIDA facility and especially that of Tomasz Chudy, Georg Scheurig and Steffen Vogt during the AQUAVIT campaigns. Special thanks also to MBW Elektronik AG, Switzerland, who always carefully serviced our reference frost-point hygrometers DP30 and who included regular comparisons of the instruments to a traceable reference water standard in the routine. Finally, we thank all the coordinators of the different field and intercomparison campaigns.

The article processing charges for this open-access publication were covered by a research center of the Helmholtz Association.

Edited by: D. J. Cziczo

\section{References}

Buchholz, B.: Entwicklung, Primärvalidierung und Feldeinsatz neuartiger, kalibrierungsfreier Laser-Hygrometer für Forschungsflugzeuge, Dissertation, 110-156, Technische Universität Darmstadt, Darmstadt, 2014.

Dessler, A. E.: Clouds and water vapor in the Northern Hemisphere summertime stratosphere, J. Geophys. Res., 114, D00H09, doi:10.1029/2009JD012075, 2009.

Diskin, G. S., Podolske, J. R., Sachse, G. W., and Slate, T. A.: Openpath airborne tunable diode laser hygrometer, Proc. SPIE, 4817, 196-204, 2002.

Engel, A., Boenisch, H., and TACTS-Team: An overview on the TACTS mission using the new German research aircraft HALO in summer 2012, EGU General Assembly 15, EGU2013-25 9191, 7-12 April 2013, Vienna, Austria, 2013.

Fahey, D. W., Gao, R.-S., Möhler, O., Saathoff, H., Schiller, C., Ebert, V., Krämer, M., Peter, T., Amarouche, N., Avallone, L. M., Bauer, R., Bozóki, Z., Christensen, L. E., Davis, S. M., Durry, G., Dyroff, C., Herman, R. L., Hunsmann, S., Khaykin, S. M., Mackrodt, P., Meyer, J., Smith, J. B., Spelten, N., Troy, R. F., Vömel, H., Wagner, S., and Wienhold, F. G.: The AquaVIT-1 intercomparison of atmospheric water vapor measurement techniques, Atmos. Meas. Tech., 7, 3177-3213, doi:10.5194/amt-7-3177-2014, 2014. 
Forster, P. M. and Shine, K. P. : Calibration and performance of automatic compact instrumentation for the measurement of relative humidity from passenger aircraft, Geophys. Res. Lett., 29, 1086, doi:10.1029/2001GL013909, 2002.

Helten, M., Smit, H. G. J., Sträter, W., Kley, D., Nedelec, P., Zöger, M., and Busen, R.: Assessing the climate impact of trends in stratospheric water vapor, J. Geophys. Res., 103, 2564325652, doi:10.1029/98JD00536, 1998.

Hurst, D. F., Oltmans, S. J., Vömel, H., Rosenlof, K. H., Davis, S. M., Ray, E. A., Hall, E. G., and Jordan, A. F.: Stratospheric water vapor trends over Boulder, Colorado: analysis of the 30 year Boulder record, J. Geophys. Res., 116, D02306, doi:10.1029/2010JD015065, 2011.

Kanzawa, H., Schiller, C., Ovarlez, J., Camy-Peyret, C., Jesek, P., Oelhaf, H., Stowasser, M., Traub, W. A., Jucks, K. W., Johnson, D. G., Toon, G. C., Sen, B., Blavier, J.-F., Park, J., Bodeker, G. E., Pan, L. L., Sugita, T., Nakajima, H., Yokota, T., Suzuki, M., Shiotani, M., and Sasano, Y.: Validation and data characteristics of water vapor profiles observed by the Improved Limb Atmospheric Spectrometer (ILAS) and processed with Version 5.20 algorithm, J. Geophys. Res., 107, 8217, doi:10.1029/2001JD000881, 2002.

Kiemle, C., Wirth, M., Fix, A., Ehret, G., Schumann, U., Gardiner, T., Schiller, C., Sitnikov, N., and Stiller, G.: First airborne water vapor lidar measurements in the tropical upper troposphere and mid-latitudes lower stratosphere: accuracy evaluation and intercomparisons with other instruments, Atmos. Chem. Phys., 8, 5245-5261, doi:10.5194/acp-8-5245-2008, 2008.

Kley, D., Russell III, J., Phillips (eds.), C., Gettelman, A., Harries, J., Mote, P., Oltmans, S., Remsberg, E., Rosenlof, K., and Schiller, C.: SPARC Assessment of Water Vapour in the Stratosphere and Upper Troposphere, WCRP-113, WMO/TD No. 1043, SPARC Report No. 2, World Climate Research Programme (WCRP), 2000.

Krämer, M., Schiller, C., Afchine, A., Bauer, R., Gensch, I., Mangold, A., Schlicht, S., Spelten, N., Sitnikov, N., Borrmann, S., de Reus, M., and Spichtinger, P.: Ice supersaturations and cirrus cloud crystal numbers, Atmos. Chem. Phys., 9, 3505-3522, doi:10.5194/acp-9-3505-2009, 2009.

Kunz, A., Schiller, C., Rohrer, F., Smit, H. G. J., Nedelec, P., and Spelten, N.: Statistical analysis of water vapour and ozone in the UT/LS observed during SPURT and MOZAIC, Atmos. Chem. Phys., 8, 6603-6615, doi:10.5194/acp-8-6603-2008, 2008.

Kunz, A., Spelten, N., Konopka, P., Müller, R., Forbes, R. M., and Wernli, H.: Comparison of Fast In situ Stratospheric Hygrometer (FISH) measurements of water vapor in the upper troposphere and lower stratosphere (UTLS) with ECMWF (re)analysis data, Atmos. Chem. Phys., 14, 10803-10822, doi:10.5194/acp14-10803-2014, 2014.

Lambert, A., Read, W. G., Livesey, N. J., Santee, M. L., Manney, G. L., Froidevaux, L., Wu, D. L., Schwartz, M. J., Pumphrey, H. C., Jimenez, C., Nedoluha, G. E., Cofield, R. E., Cuddy, D. T., Daffer, W. H., Drouin, B. J., Fuller, R. A., Jarnot, R. F., Knosp, B. W., Pickett, H. M., Perun, V. S., Snyder, W. V., Stek, P. C., Thurstans, R. P., Wagner, P. A., Waters, J. W., Jucks, K. W., Toon, G. C., Stachnik, R. A., Bernath, P. F., Boone, C. D., Walker, K. A., Urban, J., Murtagh, D., Elkins, J. W., and Atlas, E.: Validation of the Aura Microwave Limb Sounder middle atmosphere water vapor and nitrous oxide measurements, J. Geophys. Res.-Atmos., 112, D24S36, doi:10.1029/2007JD008724, 2007.

Luebke, A. E., Avallone, L. M., Schiller, C., Meyer, J., Rolf, C., and Krämer, M.: Ice water content of Arctic, midlatitude, and tropical cirrus - Part 2: Extension of the database and new statistical analysis, Atmos. Chem. Phys., 13, 6447-6459, doi:10.5194/acp13-6447-2013, 2013.

Lumpe, J., Bevilacqua, R., Nedoluha, G., Hoppel, K., Randall, C., Russell, J., Schiller, C., Sen, B., Taha, G., Toon, G., and Vömel, H.: Validation of Polar Ozone and Aerosol Measurement (POAM) III version 4 stratospheric water vapor, J. Geophys. Res., 111, D11301, doi:10.1029/2005JD006763, 2006.

Mastenbrook, H. J. and Daniels, R. E.: Measurements of stratospheric water vapor using a frost point hygrometer, in: Atmospheric Water Vapor, edited by: Deepak, A., Wilkerson, T. D., and Ruhnke, L. H., Academic Press, New York, Academic Press, 329-342, 1980.

May, R. D.: Open-path, near-infrared tunable diode laser spectrometer for atmospheric measurements of $\mathrm{H}_{2} \mathrm{O}$, J. Geophys. Res., 103, 19161-19172, doi:10.1029/98JD01678, 1998.

Milz, M., Clarmann, T. v., Bernath, P., Boone, C., Buehler, S. A., Chauhan, S., Deuber, B., Feist, D. G., Funke, B., Glatthor, N., Grabowski, U., Griesfeller, A., Haefele, A., Höpfner, M., Kämpfer, N., Kellmann, S., Linden, A., Müller, S., Nakajima, H., Oelhaf, H., Remsberg, E., Rohs, S., Russell III, J. M., Schiller, C., Stiller, G. P., Sugita, T., Tanaka, T., Vömel, H., Walker, K., Wetzel, G., Yokota, T., Yushkov, V., and Zhang, G.: Validation of water vapour profiles (version 13) retrieved by the IMK/IAA scientific retrieval processor based on full resolution spectra measured by MIPAS on board Envisat, Atmos. Meas. Tech., 2, 379-399, doi:10.5194/amt-2-379-2009, 2009.

Müller, S. C., Kämpfer, N., Feist, D. G., Haefele, A., Milz, M., Sitnikov, N., Schiller, C., Kiemle, C., and Urban, J.: Validation of stratospheric water vapour measurements from the airborne microwave radiometer AMSOS, Atmos. Chem. Phys., 8, 3169 3183, doi:10.5194/acp-8-3169-2008, 2008.

Murphy, D. M. and Koop, T.: Review of the vapour pressures of ice and supercooled water for atmospheric applications, Q. J. Roy. Meteorol. Soc., 131, 1539-1565, 2005.

Neis, P., Smit, H. G. J., Krämer, M., Spelten, N., and Petzold, A.: Evaluation of the MOZAIC Capacitive Hygrometer during the airborne field study CIRRUS-III, Atmos. Meas. Tech., 8, 1233 1243, doi:10.5194/amt-8-1233-2015, 2015.

Offermann, D., Schaeler, B., Riese, M., Langfermann, M., Jarisch, M., Eidmann, G., Schiller, C., Smit, H. G. J., and Read, W. G.: Water vapor at the tropopause during the CRISTA 2 mission, J. Geophys. Res., 107, CRI 4.1-18, doi:10.1029/2001JD000700, 2002.

Ovarlez, J.: Stratospheric water vapor measurement in the tropical zone by means of a frostpoint hygrometer on board long-duration balloons, J. Geophys. Res., 96, 15541-15545, 1991.

Peter, T., Marcolli, C., Spichtinger, P., Corti, T., Baker, M., and Koop, T.: When dry air is too humid, Science, 314, 1399-1401, 2006.

Ploeger, F., Fueglistaler, S., Grooß, J.-U., Günther, G., Konopka, P., Liu, Y. S., Müller, R., Ravegnani, F., Schiller, C., Ulanovski, A., and Riese, M.: Insight from ozone and water vapour on transport in the tropical tropopause layer (TTL), Atmos. Chem. Phys., 11, 407-419, doi:10.5194/acp-11-407-2011, 2011. 
Pruppacher, H. and Klett, J.: Microphysics of Clouds and Precipitation, Kluwer Academic Publishers, doi:10.1080/02786829808965531, Dordrecht, the Netherlands, 1997.

Read, W. G., Lambert, A., Bacmeister, J., Cofield, R. E., Christensen, L. E., Cuddy, D. T., Daffer, W. H., Drouin, B. J., Fetzer, E., Froidevaux, L., Fuller, R., Herman, R., Jarnot, R. F., Jiang, J. H., Jiang, Y. B., Kelly, K., Knosp, B. W., Kovalenko, L. J., Livesey, N. J., Liu, H. C., Manney, G. L., Pickett, H. M., Pumphrey, H. C., Rosenlof, K. H., Sabounchi, X., Santee, M. L., Schwartz, M. J., Snyder, W. V., Stek, P. C., Su, H., Takacs, L. L., Thurstans, R. P., Vomel, H., Wagner, P. A., Waters, J. W., Webster, C. R., Weinstock, E. M., and Wu, D. L.: Aura Microwave Limb Sounder upper tropospheric and lower stratospheric $\mathrm{H}_{2} \mathrm{O}$ and relative humidity with respect to ice validation, J. Geophys. Res.-Atmos., 112, D24S35, doi:10.1029/2007JD008752, 2007.

Riese, M., Ploeger, F., Rap, A., Vogel, B., Konopka, P., Dameris, M., and Forster, P. M.: Impact of uncertainties in atmospheric mixing on simulated UTLS composition and related radiative effects, J. Geophys. Res., 117, D16305, doi:10.1029/2012JD017751, 2012.

Rolf, C., Afchine, A., Bozem, H., Buchholz, B., Ebert, V., Guggenmoser, T., Hoor, P., Konopka, P., Kretschmer, E., Müller, S., Schlager, H., Spelten, N., Suminska-Ebersoldt, O., Ungermann, J., Zahn, A., and Krämer, M.: Transport of Antarctic stratospheric strongly dehydrated air into the troposphere observed during the HALO-ESMVal campaign 2012, Atmos. Chem. Phys. Discuss., 15, 7895-7932, doi:10.5194/acpd-157895-2015, 2015.

Rollins, A. W., Thornberry, T. D., Gao, R. S., Smith, J. B., Sayres, D. S., Sargent, M. R., Schiller, C., Krämer, M., Spelten, N., Hurst, D. F., Jordan, A. F., Hall, E. G., Vömel, H., Diskin, G. S., Podolske, J. R., Christensen, L. E., Rosenlof, K. H., Jensen, E. J., and Fahey, D. W.: Evaluation of UT/LS hygrometer accuracy by intercomparison during the NASA MACPEX mission, J. Geophys. Res., 119, 1915-1935, doi:10.1002/2013JD020817, 2014.

Rosenlof, K. H., Oltmans, S. J., Kley, D., Russell III, J. M., Chiou, E.-W., Chu, W. P., Johnson, D. G., Kelly, K. K., Michelsen, H. A., Nedoluha, G. E., Remsberg, E. E., Toon, G. C., and McCormick, M. P. : Stratospheric water vapor increases over the past half century, Geophys. Res. Lett., 28, 1195-1199, 2001.

Schiller, C., Krämer, M., Afchine, A., Spelten, N., and Sitnikov, N.: Ice water content of Arctic, midlatitude and tropical cirrus, J. Geophys. Res., 113, 1807-1816, doi:10.1029/2008JD010342, 2008.

Schiller, C., Grooß, J.-U., Konopka, P., Plöger, F., Silva dos Santos, F. H., and Spelten, N.: Hydration and dehydration at the tropical tropopause, Atmos. Chem. Phys., 9, 9647-9660, doi:10.5194/acp-9-9647-2009, 2009.

Schlager, H.: ESMval (Earth System Model Validation), available at: http://www.pa.op.dlr.de/ESMVal, last access: July 2014.

Sitnikov, N., Yushkov, V., Afchine, A., Korshunov, L., Astakhov, V., Ulanovskii, A., Krämer, M., Mangold, A., Schiller, C., and Ravegnani, F.: The FLASH instrument for water vapor measurements on board the high-altitude airplane, Instrum. Exp. Tech., 50, 121-129, 2007.

Smit, H., Krämer, M., Rolf, C., Spelten, N., Petzold, A., Rohs, S., Neis, P., Maser, R., Ebert, V., Bucholz, B., Bozoki, Z., Tatrai, D.,
Jones, R., Mead, M. I., and Hoff, A.: DENCHAR-Assessment Report on the Performance of a New Suite of Hygrometers for EUFAR, EUFAR FP7, EUFAR within the EU Framework Program 7, May 2014.

Smith, C. A., Haigh, J. D., and Toumi, R.: Radiative forcing due to trends in stratospheric water vapour, Geophys. Res. Lett., 28, 179-182, 2001.

Solomon, S., Rosenlof, K. H., Portmann, R. W., Daniel, J. S., Davis, S. M., Sanford, T. J., and Plattner, G.-K.: Contributions of stratospheric water vapor to decadal changes in the rate of global warming, Science, 327, 1219-1223, doi:10.1126/science.1182488, 2010.

Sonntag, D.: Advancements in the field of hygrometry, Meteorol. Z., 3, 51-66, 1994.

Spang, R., Günther, G., Riese, M., Hoffmann, L., Müller, R., and Griessbach, S.: Satellite observations of cirrus clouds in the Northern Hemisphere lowermost stratosphere, Atmos. Chem. Phys., 15, 927-950, doi:10.5194/acp-15-927-2015, 2015.

Tátrai, D., Bozóki, Z., Smit, H., Rolf, C., Spelten, N., Krämer, M., Filges, A., Gerbig, C., Gulyás, G., and Szabó, G.: Dualchannel photoacoustic hygrometer for airborne measurements: background, calibration, laboratory and in-flight intercomparison tests, Atmos. Meas. Tech., 8, 33-42, doi:10.5194/amt-8-332015, 2015.

Thomason, L. W., Moore, J. R., Pitts, M. C., Zawodny, J. M., and Chiou, E. W.: An evaluation of the SAGE III version 4 aerosol extinction coefficient and water vapor data products, Atmos. Chem. Phys., 10, 2159-2173, doi:10.5194/acp-10-2159-2010, 2010.

Thornberry, T. D., Rollins, A. W., Gao, R. S., Watts, L. A., Ciciora, S. J., McLaughlin, R. J., Voigt, C., Hall, B., and Fahey, D. W.: Measurement of low-ppm mixing ratios of water vapor in the upper troposphere and lower stratosphere using chemical ionization mass spectrometry, Atmos. Meas. Tech., 6, 1461-1475, doi:10.5194/amt-6-1461-2013, 2013a.

Thornberry, T. D., Rollins, A. W., Gao, R. S., Watts, L. A., Ciciora, S. J., McLaughlin, R. J., Voigt, C., Hall, B., and Fahey, D. W.: Measurement of low-ppm mixing ratios of water vapor in the upper troposphere and lower stratosphere using chemical ionization mass spectrometry, Atmos. Meas. Tech., 6, 1461-1475, doi:10.5194/amt-6-1461-2013, 2013b.

Vogel, B., Feck, T., and Grooß, J.-U.: Impact of stratospheric water vapor enhancements caused by $\mathrm{CH} 4$ and $\mathrm{H} 2 \mathrm{O}$ increase on polar ozone loss, J. Geophys. Res., 116, D05301, doi:10.1029/2010JD014234, 2011.

Vömel, H., David, D. E., and Smith, K.: Accuracy of tropospheric and stratospheric water vapor measurements by the cryogenic frost point hygrometer: instrumental details and observations, J. Geophys. Res., 112, D08305, doi:10.1029/2006JD007224, 2007.

Wallace, J. M. and Hobbs, P. V.: Atmospheric Science: An Introductory Survey, 2nd edn., Academic Press, Amsterdam, Elsevier Academic Press, ISBN:9780127329512, 2006.

Wang, W. C., Yung, Y. L., Lacis, A. A., Mao, T., and Hansen, J. E.: Greenhouse effects due to MAN-MADE pertubations of trace gases, Science, 194, 685-690, 1976.

Waters, J. W., Froidevaux, L., Harwood, R. S., Jarnot, R. F., Pickett, H. M., Read, W. G., Siegel, P. H., Cofield, R. E., Filipiak, M. J., Flower, D. A., Holden, J. R., Lau, G. K. K., Livesey, N. J., Manney, G. L., Pumphrey, H. C., Santee, M. L., Wu, D. L., Cuddy, D. T., Lay, R. R., Loo, M. S., Perun, V. S., 
Schwartz, M. J., Stek, P. C., Thurstans, R. P., Boyles, M. A., Chandra, K. M., Chavez, M. C., Chen, G. S., Chudasama, B. V., Dodge, R., Fuller, R. A., Girard, M. A., Jiang, J. H., Jiang, Y. B., Knosp, B. W., LaBelle, R. C., Lam, J. C., Lee, K. A., Miller, D., Oswald, J. E., Patel, N. C., Pukala, D. M., Quintero, O., Scaff, D. M., Van Snyder, W., Tope, M. C., Wagner, P. A., and Walch, M. J.: The Earth Observing System Microwave Limb Sounder (EOS MLS) on the Aura satellite, IEEE T. Geosci. Remote, 44, 1075-1092, 2006.

Weinstock, E. M., Smith, J. B., Sayres, D. S., Pittman, J. V., Spackman, J. R., Hintsa, E. J., Hanisco, T. F., Moyer, E. J., St. Clair, J. M., Sargent, M. R., and Anderson, J. G.: Validation of the Harvard Lyman- $\alpha$ in situ water vapor instrument: implications for the mechanisms that control stratospheric water vapor, J. Geophys. Res., 114, D23301, doi:10.1029/2009JD012427, 2009.
Wetzel, G., Oelhaf, H., Berthet, G., Bracher, A., Cornacchia, C., Feist, D. G., Fischer, H., Fix, A., Iarlori, M., Kleinert, A., Lengel, A., Milz, M., Mona, L., Müller, S. C., Ovarlez, J., Pappalardo, G., Piccolo, C., Raspollini, P., Renard, J.-B., Rizi, V., Rohs, S., Schiller, C., Stiller, G., Weber, M., and Zhang, G.: Validation of MIPAS-ENVISAT $\mathrm{H}_{2} \mathrm{O}$ operational data collected between July 2002 and March 2004, Atmos. Chem. Phys., 13, 5791-5811, doi:10.5194/acp-13-5791-2013, 2013.

Zöger, M., Afchine, A., Eicke, N., Gerhards, M.-T., Klein, E., McKenna, D. S., Mörschel, U., Schmidt, U., Tan, V., Tuitjer, F., Woyke, T., and Schiller, C.: Fast in situ stratospheric hygrometers: A new family of balloon-borne Lyman- $\alpha$ photofragment fluorescence hygrometers, J. Geophys. Res., 104, 1807-1816, 1999. 